DISTRIBUTION SHEET

\begin{tabular}{|c|c|c|c|c|c|}
\hline To & \multirow{2}{*}{\multicolumn{3}{|c|}{$\begin{array}{l}\text { From } \\
\text { B. H. Johnson }\end{array}$}} & \multicolumn{2}{|l|}{ Page 1 of 1} \\
\hline Distribution & & & & \multicolumn{2}{|c|}{$\begin{array}{l}\text { Date October 24, } \\
1994\end{array}$} \\
\hline \multirow{2}{*}{\multicolumn{4}{|c|}{ Project Title/Work Order }} & \multicolumn{2}{|c|}{ EDT No. 600674} \\
\hline & & & & \multicolumn{2}{|l|}{ ECN No. $N / A$} \\
\hline Name & MSIN & $\begin{array}{c}\text { Text } \\
\text { With All } \\
\text { Attach. }\end{array}$ & Text Only & $\begin{array}{l}\text { Attach./ } \\
\text { Appendix } \\
\text { Only }\end{array}$ & $\begin{array}{l}\text { EDT/ECN } \\
\text { Only }\end{array}$ \\
\hline
\end{tabular}

MACTEC

G. D. Burdsal1

R. E. Conrad

$\underline{\mathrm{RL}}$

C. P. Christianson

O. M. Holgado

J. K. Schmitz

D. H. Splett

WHC

B. S. Carlisle

J. C. Hamrick

G. Hansrote

J. M. Henderson

B. H. Johnson

J. D. Mathews

C. F. Myott

T. J. Ruane

J. P. Schmidt

S. A. Slinn

C. A. Thompson

J. E. Truax

S. C. Wallace

Central Files

OSTI (2)

PSC (2)

$\begin{array}{ll}\text { R3-82 } & X \\ A 4-35 & X\end{array}$

A5-55

R3-81

A5-18

R3-81

$$
\begin{aligned}
& X \\
& X \\
& X \\
& X
\end{aligned}
$$

$\times 3-71$

$\times 0-22$

R3-85

R3-85

R3-85

$\times 3-61$

$\times 0-22$

$\times 3-65$

$\times 3-78$

$\times 3-74$

$\times 3-72$

$\times 3-71$

$\times 3-74$

L8-04

L8-07

A2-18

$x$
$x$
$x$
$x$
$x$
$x$
$x$
$x$
$x$
$x$
$x$
$x$
$x$
$X$
$x$
$x$




\begin{tabular}{|l|l|}
\hline $\begin{array}{l}\text { 2. To: (Receiving organization) } \\
\text { Distribution }\end{array}$ & $\begin{array}{l}\text { 3. From: Coriginating } \\
\text { Project Engineer } \\
\text { Integration }\end{array}$ \\
\hline $\begin{array}{l}\text { 5. Proj./Prog./Dept./Div.: } \\
\text { K Basin Essential Systems } \\
\text { Recovery, Project W-405 }\end{array}$ & $\begin{array}{l}\text { 6. Cog. Engr.: } \\
\text { B. H. Johnson }\end{array}$ \\
\hline
\end{tabular}

8. Originator Remarks:

A waiver has been granted by RL Project Management Division from the requirement to utilize the metric system of measurement for Project $W-405$.

Ref: Chin, W. S., 1994, PROJECT W-405, K-BASIN STABILIZATION \& TRANSITION, WAIVER FROM REQUIREMENT TO USE THE METRIC SYSTEM OF MEASUREMENT, (letter, 94-PMD-135 to President, Westinghouse Hanford Company, June 22), U. S. Department of Energy Richland Field Office, Richland, Washington

11. Receiver Remarks:
4. Related EDT No.:

$N / A$

7. Purchase Order No.:

WHC-MRY-SVV-293887

9. Equip./Component No.:

$$
N / A
$$

10. System/Bldg./Facility:

$$
\text { 24/105KE, } 105 \mathrm{KW} / 100 \mathrm{~K}
$$

12. Major Assm. Dwg. No.:

$$
N / A
$$

13. Permit/Permit Application No.:

$$
N / A
$$

14. Required Response Date: November 11, 1994

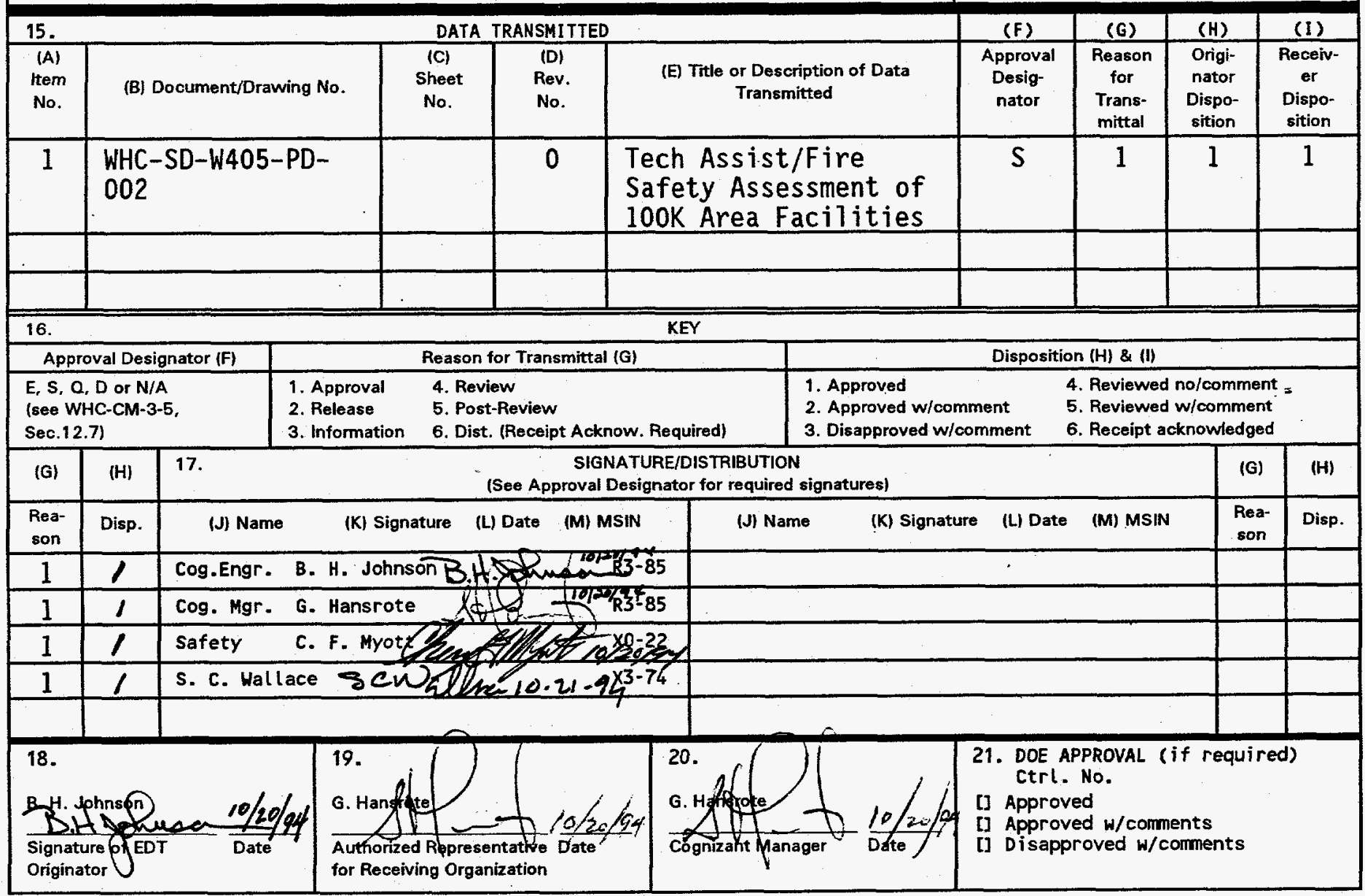




\section{DISCLAIMER}

Portions of this document may be illegible in electronic image products. Images are produced from the best available original document. 


\section{RELEASE AUTHORIZATION}

Document Number: WHC-SD-W405-PD-002, REV 0

Document Title: Tech. Assist/Fire Safety Assessment of 100K Area Facilities

Release Date: $10 / 24 / 94$

\section{$* * * * * * * * * * *$ \\ This document was reviewed following the procedures described in WHC-CM-3-4 and is:}

APPROVED FOR PUBLIC RELEASE

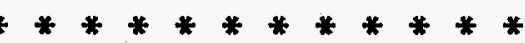

WHC Information Release Administration Specialist:

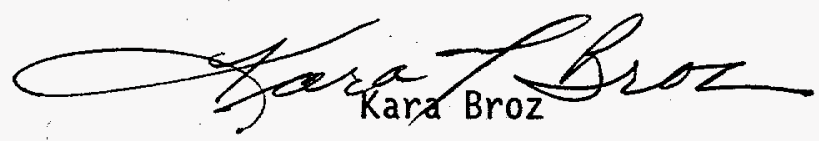

(Signature)

October 24, 1994

(Date)

TRADEMARK DISCLAIMER. Reference herein to any specific commercial product, process, or service by trade name, trademark, manufacturer, or otherwise, does not necessarily constitute or imply its endorsement, recommendation, or favoring by the United States Government or any agency thereof or $i$ ts contractors or subcontractors.

This report has been reproduced from the best available copy. Available in paper copy and microfiche. Printed in the United States of America. Available to the U.S. Department of Energy and its contractors from

U.S. Department of Energy

office of Scientific and Technical Information (OSTI)

P.0. Box 62

Oak Ridge, TN 3783

Telephone: (615) 576-8401

Available to the public from the U.S. Department of Commerce

National Technical Information Service (NTIS)

5285 Port Royal Road

Springfield, VA 22161

(703) $487-4650$ 
2. Title

Tech Assist/Fire Safety Assessment of 100K Area Facilities

5. Key Words

100K Area, 105KE, 105KW, K Basins, Fire Safety, Project $W-405$

\section{APPROVED FOR PUBLIC RELEASE}

3. Number

WHC-SD-W405-PD-002 4. ReV No.

0
6. Author

Name: B. H. Johnson

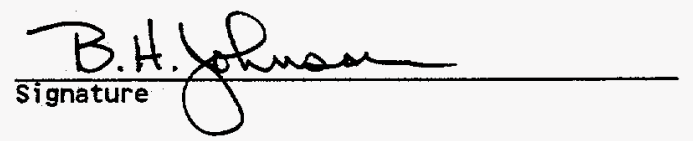

Organization/Charge code 7FA20/L123B

7. Abstract

This Tech Assist/Fire Safety Assessment provides a comprehensive assessment of the 100K Area Facilities at the U. S. Department of Energy's Hanford Site for fire protection upgrades that may be needed given the limited remaining service life of these facilities.

This assessment considers the relative nature of observed fire risks and whether the installed fire protection systems adequately control this risk. The analysis is based on compliance with DOE Orders, NFPA Codes and Standards, and recognized industry practice. Limited remaining service life (i.e., 6 to 12 years), current value of each facility, comparison to the best protected class of industrial risk, and the potential for exemptions from DOE requirements are key factors for recommendations presented in this report.

8. TuRPOSE AND USE OF DOCUMENT - This document was prepared use within the U.S. Department of Energy and its contractore? It is to be used ouly to perform, direct, or integrate work under U.S. Department Energy contracts. This dotument is not approved for public release until reviewed.

PATENT STATUS - This dorament copy, since it is transmitted in advance of patent ctrarance, is made available in confidence solely for use in performance of work undac contracts with the U.S. Department of Energy. This document is noto be published nor its contents otherwise disseminated or used for purpeces other than specified above before patent approval for such release on use has been secured, upon request, from the Patent Counsel, U.S. Departmegt of Energy field Office, kichland, WA.UISCLATMER - ThIs report pas prepared as an account of work sponsored by an agency of the United States Government. Neither the United States Government nor any agency thereof, nor any of their employees, nor any of their contractors, subcontractors or their employees, makes any warranty, express or implied, or assumes any legal liability or responsibility for the accuracy, completeness, or any third party's use or the results of such use of any information, apparatus, product, or process disclosed, or represents that its use would not infringe privately owned rights. Reference herein to any specific commercial product, process, or service by trade name, trademark, manufacturer, or otherwise, does not necessarily constitute or imply its endorsement, recommendation, or favoring by the United States Government or any agency thereof or its contractors or subcontractors. The views and opinions of authors expressed herein do not necessarily state or reflect those of the United States Government or any agency thereof.

9. Impact Level $\mathbf{S}$
10. RELEASE STAMP

OFFICIAL BELFESE (2. syviric

DATE OCT 241994

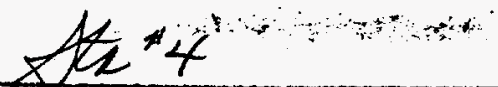




\title{
TECH ASSIST/FIRE SAFETY ASSESSMENT OF 100K AREA FACILITIES
}

\section{K BASINS ESSENTIAL SYSTEMS RECOVERY, PROJECT W405}

\author{
Prepared For \\ Westinghouse Hanford Company \\ P.O. Box 1970 \\ Richland, Washington 99352
}

\begin{abstract}
Prepared By
Columbia Energy and Environmental Services, Inc. 1207 George Washington Way, Suite 22

Richland, Washington 99352
\end{abstract}

October 12, 1994 


\section{TABLE OF CONTENTS}

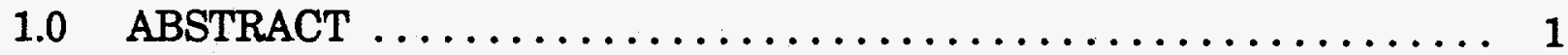

$2.0 \quad$ EXECUTIVE SUMMMARY $\ldots \ldots \ldots \ldots \ldots \ldots \ldots \ldots \ldots \ldots \ldots \ldots \ldots \ldots \ldots$

3.0 OBJECTIVE $\ldots \ldots \ldots \ldots \ldots \ldots \ldots \ldots \ldots \ldots \ldots \ldots \ldots \ldots \ldots \ldots \ldots \ldots$

3.1 PURPOSE AND NEED $\ldots \ldots \ldots \ldots \ldots \ldots \ldots \ldots \ldots \ldots \ldots, 3$

3.2 BACKGROUND $\ldots \ldots \ldots \ldots \ldots \ldots \ldots \ldots \ldots \ldots \ldots \ldots$

3.3 PROJECT SCOPE $\ldots \ldots \ldots \ldots \ldots \ldots \ldots \ldots \ldots \ldots \ldots \ldots$

4.0 CONCLUSIONS ........................... 5

4.1 DAVID GESSERT'S CONCLUSIONS $\ldots \ldots \ldots \ldots \ldots \ldots \ldots, 5$

4.2 JACK POOLE'S CONCLUSIONS $\ldots \ldots \ldots \ldots \ldots \ldots \ldots \ldots, 5$

5.0 RESULT OF THE WALK-DOWNS $\ldots \ldots \ldots \ldots \ldots \ldots \ldots \ldots \ldots \ldots$

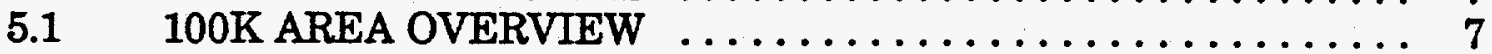

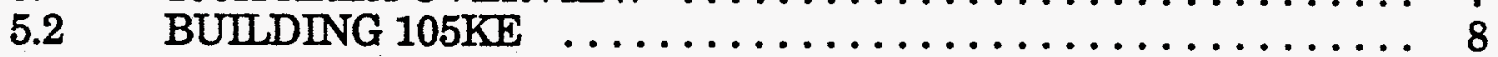

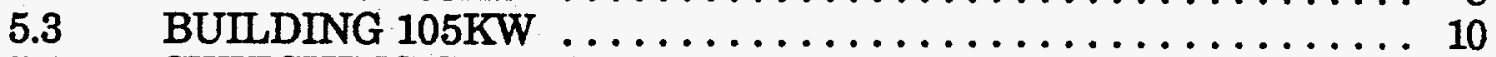

5.4 SWITCHING STATION $151 \mathrm{~K} \ldots \ldots \ldots \ldots \ldots \ldots \ldots \ldots \ldots \ldots$

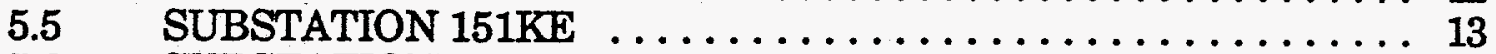

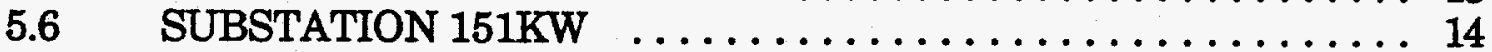

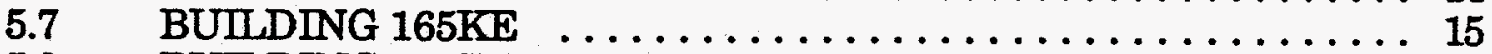

5.8 BUILDING $165 \mathrm{KW} \ldots \ldots \ldots \ldots \ldots \ldots \ldots \ldots \ldots \ldots \ldots \ldots \ldots \ldots$

5.9 BUILDING/TUNNEL $167 \mathrm{~K} \ldots \ldots \ldots \ldots \ldots \ldots \ldots \ldots \ldots \ldots$

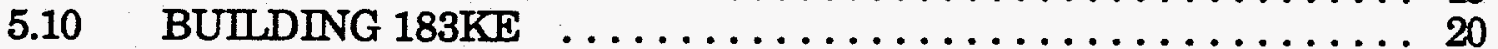

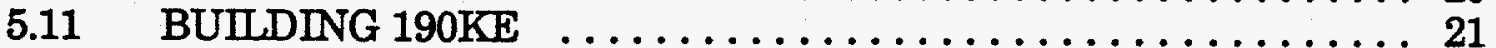

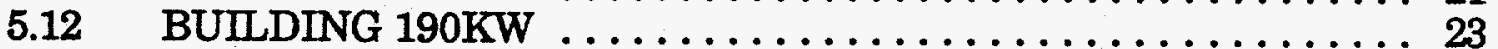

5.13 BUILDING 1706KE/KEL $\ldots \ldots \ldots \ldots \ldots \ldots \ldots \ldots \ldots \ldots \ldots 24$

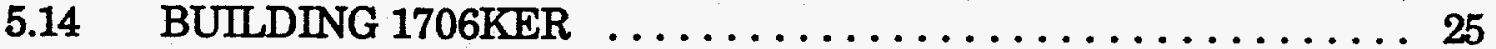

5.15 BUILDING $1717 \mathrm{~K} \ldots \ldots \ldots \ldots \ldots \ldots \ldots \ldots \ldots \ldots \ldots \ldots \ldots$

6.0 CONSULTANTS EVALUATIONS/RECOMMENDATIONS . . . . . . 29

6.1 DAVID GESSERT'S EVALUATION/RECOMMENDATIONS $\ldots 29$

6.2 JACK POOLE'S EVALUATION/RECOMMENDATIONS $\ldots . .35$

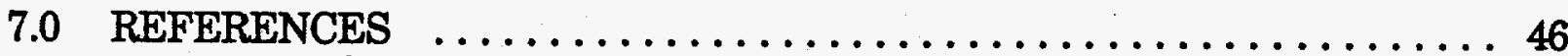

$7.1 \quad$ FACILITY DOCUMENTATION $\ldots \ldots \ldots \ldots \ldots \ldots \ldots \ldots \ldots \ldots \ldots \ldots \ldots \ldots$

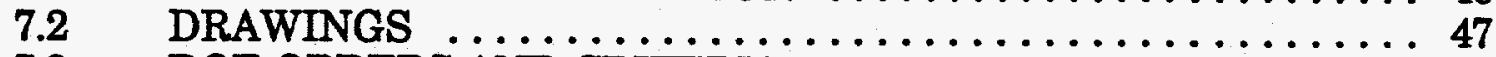

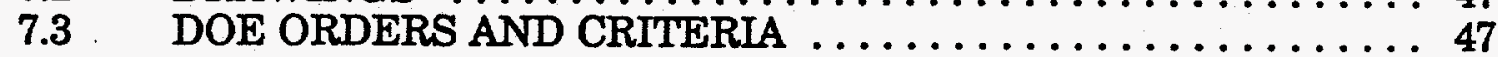

7.4 NATIONAL FIRE PROTECTION ASSOCIATION

CODES/STANDARDS ..................... 48

7.5 FACTORY MUTUAL LOSS PREVENTION DATA SHEETS $\ldots 48$

7.6 OTHER DOCUMENTS $\ldots \ldots \ldots \ldots \ldots \ldots \ldots \ldots \ldots \ldots \ldots$ 
WHC-SD-W405-PD-002, Rev. 0

\section{ABBREVIATIONS, ACRONYMS, AND INITIALISMS}

\begin{tabular}{|c|c|}
\hline ANI & American Nuclear Insurers \\
\hline dia. & diameter \\
\hline D\&D & Decontamination and Decommission \\
\hline DOE & Department of Energy \\
\hline FHA & Fire Hazards Analysis \\
\hline FM & Factory Mutual \\
\hline $\mathrm{ft}$ & feet or foot \\
\hline $\mathrm{ft}^{2}$ & square feet \\
\hline HFD & Hanford Fire Department \\
\hline $\mathrm{hr}$ & hour(s) \\
\hline in. & $\operatorname{inch}(e s)$ \\
\hline gal & gallon(s) \\
\hline $\mathrm{MCC}$ & Motor Control Center \\
\hline $\min$. & minute(s) \\
\hline MPFL & Maximum Possible Fire Loss \\
\hline NFPA & National Fire Protection Association \\
\hline RFAR & Radio Fire Alarm Reporting \\
\hline SFPE & Society of Fire Protection Engineers \\
\hline UBC & Uniform Building Code \\
\hline Westinghouse Hanford & Westinghouse Hanford Company \\
\hline $105 \mathrm{KE}$ & Building $105 \mathrm{~K}$ East, Reactor Facility \\
\hline $105 \mathrm{KW}$ & Building 105K West, Reactor Facility \\
\hline $151 \mathrm{~K}$ & Switching Station \\
\hline $151 \mathrm{KE}$ & Substation 230-KV, East \\
\hline $151 \mathrm{KW}$ & Substation 230-KV, West \\
\hline $165 \mathrm{KE}$ & East Power Control Building \\
\hline $165 \mathrm{KW}$ & West Power Control Building \\
\hline $167 \mathrm{~K}$ & Cross Tie Tunnel Building \\
\hline 183KE & Filter Plant Head House/Chlorine Vault \\
\hline $190 \mathrm{KE}$ & East Main Pump House \\
\hline
\end{tabular}


WHC-SD-W405-PD-002, Rev. 0

\section{ABBREVIATIONS, ACRONYMS, AND INITIALISMS (CONTINUED)}

$190 \mathrm{KW}$

1706KE/KEL

1706KER

$1717 \mathrm{~K}$
West Main Pump House

Water Studies/Environmental Laboratory

Water Studies Recirculation Building

Maintenance Transportation Shop Building 


\subsection{ABSTRACT}

The Tech Assist/Fire Safety Assessment is intended to provide a comprehensive assessment of the 100K Area Facilities at the Department of Energy (DOE) Hanford Site for fire protection upgrades that may be needed given the limited remaining service life of these facilities. The assessment has been prepared according to the Statement of Work submitted to Columbia Energy \& Environmental Services, Inc. (Columbia Energy) under Purchase Order M-293887, Task Number 94-11 and the amended building list per cc: Mail Memorandum To: S.C. Wallace, From: B.H. Johnson July 25, 1994, Subject: Fire Protection Consultant Visit (WHC 1994d). The assessment of these facilities and the development of this report was prepared by two individual Registered Fire Protection Engineers, David Gessert, PE, of Columbia Energy and Jack Poole, PE, of Poole Fire Protection Engineering, Inc.

The approach taken to complete this assessment was to identify the fire risks present in the building, identify the equipment and its value to $\mathrm{DOE}$, identify the fire barriers and related materials used for the construction of the buildings, determine the adequacy of or the absence of the fire protection systems, and determine the adequacy of the means of egress to identify the fire protection upgrades in the facilities as listed below.

Building 105KE
Switching Station 151K
Substation 151KW
Building 165KW
Building 183KE
Building 190KW
Building 1706KER

Building 105KW
Substation 151KE
Building 165KE
Building/Tunnel 167K
Building 190KE
Building 1706KE/KEL
Building 1717K

Information contained in this report was obtained from walk-downs of each facility listed above and the references listed in Section 7.0 of this report.

After the walk-downs were completed and the referenced documents were reviewed, an analysis was performed to determine the relative nature of the fire risks, and whether the installed fire protection is adequately controls these risks. The analysis was made based on compliance with DOE Orders, National Fire Protection Association (NFPA) Codes and Standards, and recognized industrial practice. Limited remaining ${ }^{2}$ service life (i.e., 6 and 12 years remaining), current value of each facility, comparison to best protected class of industrial risk, and the potential for exemptions from DOE requirements for each facility were all key factors to the recommendations. Future use of these facilities by the private sector has not been considered in this assessment report. Concerns such as the life safety of the building occupants and possible environmental damage from a fire incident were essential considerations in the analysis. 
WHC-SD-W405-PD-002, Rev. 0

\subsection{EXECUTIVE SUMMARY}

After completion of $100 \mathrm{~K}$ Area facility walk downs, evaluation of referenced documentation, and group consultations with Westinghouse Hanford Company (Westinghouse Hanford) personnel, both Fire Protection Engineers are recommending upgrades and exemption requests from DOE Order 5480.7A requirements as listed in Section 6.0.

The overall good housekeeping and maintenance that the facilities are receiving and their limited remaining life were key considerations to the recommendations.

Both engineers that developed this report have common thoughts for the corrective action that should take place for these facilities. It is the opinion of these engineers that if the facility construction is noncombustible, the combustible loading is low and the ignition sources are limited, that the retrofit of an automatic sprinkler system is not justified for a facility that is 30 years old and has a limited remaining service life of 6 to 12 years. Therefore, these engineers have recommended that exemption requests be submitted for most of the facilities that have an MPFL of greater than $\$ 1$ million, except certain facilities as noted in Section 6.0.

The primary difference between the independent reviews by Mr. Gessert and Mr. Poole is that Mr. Gessert feels that the recommendations for a remaining service life of six years is no different from the recommendations for a facility with a 12-year remaining service life. Mr. Poole believes that if the facility has a remaining service life of 12 years and if the building is going to be used and occupied, the fire alarm system should be upgraded to a system that provides supervision as required by the applicable codes and standards. 


\subsection{OBJECTIVE}

\subsection{PURPOSE AND NEED}

This assessment's purpose is to assess comprehensively the risk from fire within each facility, in relation to existing or proposed fire protection features, and to identify the recommended fire protection upgrades for each facility. The assessment shall evaluate the construction, occupancy, fire protection features and the housekeeping for each facility with respect to the fire protection requirements of DOE Orders, NFPA Codes and Standards and recognized industrial practice.

Because of the assessment, the recommended fire protection upgrades shall be identified based upon an acceptable level of protection for an economical cost considering the limited remaining service life of each facility. These fire protection upgrades shall be implemented to upgrade these facilities to provide an acceptable level of life safety and fire protection for the facility occupants and the property.

\subsection{BACKGROUND}

The 100K Area Facilities are located near the Columbia River at the 100KE and 100KW Reactor Sites north of Richland, Washington. The facilities were built in the early 1950 s with a 20 -year design life.

These facilities house and support the near term storage mission for spent nuclear fuel at the Hanford Site. Near term spent nuclear fuel storage in the $105 \mathrm{KE}$ and $105 \mathrm{KW}$ facilities is targeted for completion by December 2002; therefore, these facilities have a limited remaining service life. There has been much discussion about the use of retired DOE Hanford facilities by the private sector. However, the only facilities that have been discussed for future use in the $100 \mathrm{~K}$ Area are the water retention basins adjacent 183KE. The proposed use of these basins is a fish hatchery.

DOE Fire Protection Program (DOE 1993) requires that DOE facilities be protected from damage and loss due to fire at a level consistent with the best protected class of industrial risk, including compliance with the Life Safety Code (NFPA 101) and other applicable NFPA Codes and Standards.

The scope of Project N037, 100K Area Fire Protection Upgrades, has been superseded by the Fire Protection Upgrade Task of Project W405, $K$ Basin Essential Systems Recovery. The initial scope of the Project W405 Fire Protection Upgrade Task is taken from a 1994 engineering study, minus those preferred alternatives that could be resolved without the need for modifications.

This report is to assist Westinghouse Hanford in finalizing the scope of the Fire Protection Upgrades Task for Project W405 with the assistance of Westinghouse Hanford Engineering staff and DOE Fire Protection Engineers.

\subsection{PROJECTSCOPE}

Scope of work shall include technical assistance directed at assessing the $100 \mathrm{~K}$ Area facilities for fire protection upgrades that may be needed given the limited 
remaining service life of these facilities and finalizing the scope of the Fire Protection Upgrades task of Project W405, K Basin Essential Systems Recovery.

An independent assessment by two qualified Fire Protection Engineers shall be incorporated into a single report to address the $100 \mathrm{~K}$ Area facilities. Two Fire Protection Engineers, acting independently, shall take part in the following activities:

- Walk-downs of the 100K Area facilities, as listed in Section 1.0, for gathering data, visual observation, and assessment.

- Using various inputs available from WHC studies and documentation in carrying out this scope of work.

- Sessions directed at finalization of Project W405 Fire Protection Upgrades Task scope and determining what, if any, exemptions should be applied for.

A report shall be developed to describe the group activities leading up to the finalized scope. The report shall include an assessment of the need for recommended fire protection upgrades assuming 6 and 12 years of remaining service life. The report is not intended to identify specific code deficiencies/findings nor provide the level of analytical detail of a full Fire Hazard Analysis (FHA); however, it is intended to evaluate the "big picture" of the facilities and identify the key items of concern, i.e., life safety, fire barriers, fire suppression systems, fire alarm and detection systems. 


\subsection{CONCLUSIONS}

\subsection{DAVID GESSERT'S CONCLUSIONS}

To protect against the risk of fire and fire related perils, a comprehensive or "defense in depth," approach is taken. Under this approach all aspects of fire protection are considered; namely, fire barriers, automatic fire suppression, manual fire suppression, automatic fire alarm, manual fire alarms, fire department response, testing, maintenance, administrative controls, and employee training. Not all these areas were investigated to the degree of compliance with the best protected class of industrial risk, but all were considered or sampled randomly to obtain the "big picture" of fire safety assessment of $100 \mathrm{~K}$ Area facilities.

Recommendations in Section 6.0 are based on life safety concerns, the need to provide economic solutions to complex engineering problems, and experience working in both private industry and commercial nuclear power. Readers of this report are encouraged to keep in mind the goals and objectives that Westinghouse Hanford has set; namely, to provide cost-effective solutions while maintaining excellence in conduct of operations.

Recommendations in Section 6.0 do not make a differentiation between 6 and 12-year remaining life. The facility would have to have at least a 20 -year remaining life to warrant any additional fire protection upgrades over the basic recommendations. The 20-year cutoff is based on one-half the normal life of $\mathbf{4 0}$ years of an industrial facility.

The lack of fire alarm system supervision is not a concern up to a 20-year remaining life. This is because supervision of the alarm system was not required by the code of record at the time of original installation. Problems with the system will be identified by the Hanford Fire Department (HFD) testing program. Two incidents have to occur simultaneously to challenge an unsupervised fire alarm system. Those incidents are:

- The system has to be in a non-operational condition that has not been identified, and

- There has to be a need for the system to function (a fire).

The probability of both occurring simultaneously is low. This is a reasonable risk to accept.

Several exemptions are recommended in Section 6.0. Additional justification and analysis should accompany the exemption requests.

\subsection{JACK POOLE'S CONCLUSIONS}

The approach taken by Mr. Poole was to use the standard industry practice, as well as to incorporate the requirements of DOE Orders and NFPA Codes and Standards into this evaluation. Providing economically feasible solutions to life safety and property protection issues for these facilities were an important part of the approach. Under this approach all aspects of fire protection are considered; namely, life safety and egress 
components, fire barriers, automatic fire suppression, manual fire suppression, automatic fire alarm, manual fire alarms, fire department response, testing, maintenance, administrative controls, and employee training. Not all these areas were investigated to the degree of compliance with the best protected class of industrial risk, but all were considered or sampled randomly to obtain the "big picture" of fire safety assessment of $100 \mathrm{~K}$ Area facilities.

The recommendations proposed in Section 6.0 are based upon the life safety concerns of the facility and the limited remaining service life. There are no recommendations to install sprinklers in any of the buildings unless they contain storage of equipment that is high in value and is required for operation of the $\mathrm{K}$ Area facilities or the decontamination and decommission (D\&D) activities.

These recommendations do not include the upgrade of the fire alarm system to a supervised system for the buildings that have a service life of 6 years or less. This decision is based upon the fact that the code of record for the fire alarm system (when it was installed) did not require supervision and the fact that the systems are tested and maintained on a normal frequency. Testing documentation was reviewed and found acceptable.

The recommended exemption requests as listed in Section 6.0 are based upon comparison to how fire risk is managed in an industrial facility. When these exemption requests are submitted to DOE, additional justification should be provided for each to justify the request. 


\subsection{RESULT OF THE WALK-DOWNS}

\subsection{TOOK AREA OVERVIEW}

\subsubsection{Water Distribution System}

The existing water distribution system is supplied from the Columbia River. This water is pumped from a pumping station to the holding basins at $183 \mathrm{KE}$. Water is then gravity fed through filters to the clearwell at $190 \mathrm{KE}$. Service water pumps in $190 \mathrm{KE}$ draw suction from the clearwell. The service water pumps supply the 6-in.-dia. underground water distribution system for the $100 \mathrm{~K}$ Area facilities. These service water pumps are not UL Listed fire pumps. Most of the piping is routed through the tunnels that interconnect the majority of the facilities. The existing fire hydrants are supplied from this service water system. There are redundant electric pumps at the river pumping station and in $190 \mathrm{KE}$. However, these pumps are supplied from the same electrical distribution system and the second pump requires manual starting.

Project W-405 includes a Water Supply and Distribution System Task that proposes to use the two 188,000-gal (gross capacity) stainless steel tanks located south of $183 \mathrm{KE}$ as the fire water storage tanks. Two new fire pumps will be installed. It is undetermined as of the date of this report if the pumps will be two electric pumps provided with an emergency electrical power source (generator) or one electric and one diesel fire pump. These two pumps had not been designed at the time this report was developed, but it is critical that these pumps are sized to handle the largest fire water demand, inclusive of hose streams, for the $100 \mathrm{~K}$ Area facilities. The largest fire water demand most likely would be the new office, maintenance shop and storage area being considered for $190 \mathrm{KE}$. Two existing 10-in.-dia. glycol mains located in the cross-tie tunnel will be used as the fire water distribution system. The glycol lines do not provide a true fire loop around the facilities, but are looped and provide redundancy.

\subsubsection{Fire Department Response}

The HFD consists of four fire stations covering the 560 square mile Hanford Site. These stations are strategically located across the site to ensure minimum response time to all facilities. Front-line engines in all stations are aerial device/pumpers, with additional pumpers for backup. The HFD maintains 39 vehicles representing a diversified range of capabilities. Of these, 29 are specifically equipped fire/emergency response apparatus, 24 are first-line apparatus, and five are listed as backup (reserve) apparatus.

The 100 Area Fire Station is the closest to the 100K Area Facilities. This station is located midway between $100 \mathrm{~K}$ Area and $100 \mathrm{~N}$ Area. Estimated response time, from the time the alarm is received at the central dispatch/communications center until the time the first piece of fire apparatus arrives on the scene of an incident at the 100K Area, is four to five min. This response time assumes the fire fighters are in the 100 Area Fire Station and normal road and traveling conditions exist.

The present scenario for a Hanford Site Fire Emergency Response is to dispatch a single aerial device/pumper from the fire station closest to the incident with a backup aerial device/pumper from the next closest fire station to the incident. This provides a 
two-engine response. The first engine due constitutes what is termed "Initial Attack Response Capability."

The HFD has an established mutual/automatic aid agreement with the surrounding jurisdictions. The agreement enables (and obligates) the HFD to augment its own fire and emergency medical resources in case of large fires, conflagrations, or other disasters. This agreement, known as the "Tri-Cities Mutual Aid Agreement," has been in existence at least since 1985 and includes the cities of Richland, Kennewick and Pasco and the Fire Protection Districts of Benton County \#1, Benton County \#2, Benton County \#3, Benton County \#4, Benton County \#5, Benton County \#6, Franklin County \#3 and Walla Walla County \#5. Participation in the agreement is delivered using existing labor and equipment.

\subsubsection{Testing/Maintenance of Fire Protection Systems}

The fire suppression and detection systems are tested by the HFD. Random sampling of the testing documentation for the $100 \mathrm{~K}$ Area facilities was reviewed and no discrepancies were noted. This testing documentation is maintained at Building 609G. Emergency lighting and exit signs throughout the facilities are maintained by building management. A random sampling of emergency lights and exit signs were tested during the walk-downs and no deficiencies were noted with respect to their operation.

\subsubsection{Administrative Procedures}

Administrative procedures for hot work and the control of combustibles were reviewed and no discrepancies were noted. The employees of the areas are cognizant of the hot work requirements and the need to limit the accumulation of transient combustibles.

Employees of the $\mathrm{K}$ Basin Facilities were randomly interviewed as to their response in the event of a fire. While the results of theses interviews may not represent the total employee populations, they were adequate. However, there could be a stronger and more uniform understanding on the part of the employees of management's expectations of their response in the event of a fire.

\subsection{BUILDING 105KE}

\subsubsection{Construction}

Building $105 \mathrm{KE}$ was originally constructed in the 1950 s as a graphite moderated plutonium producing reactor using once-through cooling. Production ceased when the reactor was shut down in February 1971 . The $30,000 \mathrm{ft}^{2}$ deactivated facility is built of noncombustible construction. The roof covering is built-up asphalt and gravel on a transite deck. Exterior walls are windowless and constructed of reinforced concrete or transite on steel frame and beam. Interior walls are reinforced concrete or gypsum board. Floors are reinforced concrete. There are no qualified fire barriers, thus only one fire area. Interior surfaces are finished with paint. Building $105 \mathrm{KE}$ has eight basic levels with all levels deactivated except part of the 0 -ft, 0 -in. level. 
A Westinghouse Hanford document, WHC-IP-0022 (WHC, 1987), is assumed to support the conclusion that the graphite reactor core constitutes no fire hazard. However, this document was not reviewed by either Fire Protection Consultant during this assessment.

\subsubsection{Occupancy/Life Safety Features}

According to NFPA 101, Life Safety Code, this facility has a classification of Special Purpose Industrial. Occupancy of the activated area of this facility is storage of N Reactor Spent Fuel. The active areas consist of approximate areas between column lines 1 through 16 and column lines A through G, column lines 1 through 5 and column lines $G$ through $L$, and the electrical equipment room located between column lines 12.1 and 15.5 and column line $\mathrm{G}$ through $\mathrm{H}$.

The inactive portion of the building is for the most part not used, except for storage of material at the face of the reactor. Most of the stored material is in wood crates.

Special hazards consist of radiation, radioactive contamination, and plutonium fuel storage in the basin.

The Life Safety Code requires emergency lighting and exit signs. There are no deficiencies with respect to the exit signs, but the emergency lighting is inadequate according to NFPA 101. There is current work package (JCS 1N-92-00303/M) to upgrade the emergency lighting in $105 \mathrm{KE}$. The number of exits, travel distances, exit width and direction of door swing is adequate with respect to the Life Safety Code.

\subsubsection{Fire Protection Features}

Part of the active portions of the 0 -ft, 0 -in. level are provided with automatic sprinkler protection supplied by a 4-in. connection to the 8-in. service water main in Corridor 5. A vane-type water flow switch is provided in the 4-in. line that transmits and alarm signal to the RFAR box.

Portable fire extinguishers are located throughout the active areas and in some deactivated areas of the facility. There are five manual pull boxes in the facility.

The control room and transformer vault, in the inactive portion of the building, are provided with eight Fenwal heat detectors. Heat detectors, manual pulls, and water flow alarms are transmitted to the HFD via the RFAR System Box 1250.

Facility Pre-Fire Plans exist with the most recent revision being issued in January 1992. The Pre-Fire Plan is not current because the most recent Pre-Fire Plan for this facility is dated January 1992 and was to be updated every year. Though the PreFire Plan was not updated in December 1994 the information in the January 1992 PreFire Plan is current.

\subsubsection{Fire Barriers}

When the facility was constructed in the early 1950 s there were no identified fire barriers. Based upon the Fire Barrier Evaluation of the Wall Between Spent Nuclear 
Fuel Storage Basins and Reactor Areas, 105KE and 105KW (WHC 1994b), the barrier that separates the active areas from the D\&D areas is required to have a 2-hr fire resistance rating to divide the facility into two separate fire areas. This report identifies the recommended upgrades to qualify this barrier as an equivalent 2-hr fire resistive barrier.

\subsubsection{Fire Suppression Systems}

For strict compliance with DOE Order 5480.7A, the entire facility is required to have an automatic suppression system if the MPFL is determined (via FHA calculations) to be greater than $\$ 1$ million. If an FHA determines the D\&D areas to have an MPFL of less than $\$ 1$ million and the fire barrier that separates the active areas from the D\&D areas is upgraded to a minimum of 2-hour fire resistance rating, then the only area required to be upgraded with a complete automatic suppression system will be the active areas. The office area is partially sprinklered, but the basin area is not. Additional sprinklers are required in the office areas, the basement below the office, and in the basin area to meet DOE Order 5480.7A.

\subsubsection{Fire Alarm and Detection Systems}

The current fire alarm system in the facility complies with the requirements of DOE Order 5480.7A and NFPA with the exception that the initiating, and indicating circuits are not supervised as specified in NFPA 72.

\subsubsection{Housekeeping}

Housekeeping was very good in the personnel support areas. The area had ongoing activities taking place in it but transient combustibles were kept low. Housekeeping was very good in the basins area with almost no transient combustibles present. Stored material in wood crates was located by the reactor face in the inactive portion of the facility.

\subsection{BUILDING 105KW}

\subsubsection{Construction}

Building $105 \mathrm{KW}$ was originally constructed in the 1950 s as a graphite moderated plutonium producing reactor using once-through cooling. The reactor was shut down in February 1970. The $30,000 \mathrm{ft}^{2}$ deactivated facility is built of noncombustible construction. There is a standing seam metal roof 5 to $8 \mathrm{ft}$ over the original built-up asphalt and gravel on a transite deck. Windowless exterior walls are reinforced concrete or transite on steel frame and beam. Interior walls are reinforced concrete or gypsum board. Floors are reinforced concrete. There are no fire barriers and one fire area. Interior surfaces are finished with paint. Building $105 \mathrm{KW}$ has eight basic levels with all levels deactivated except part of the 0 -ft, 0 -in. level.

A Westinghouse Hanford document, WHC-IP-0022 (WHC 1987), is assumed to support the conclusion that the graphite reactor core forms no fire hazard. However, this document was not reviewed by either Fire Protection Consultant during this assessment. 


\subsubsection{Occupancy/Life Safety Features}

Following NFPA 101, Life Safety Code, this facility has a classification of Special Purpose Industrial. Occupancy of the activated area of this facility is storage of $\mathbf{N}$ Reactor Spent Fuel. The active areas consist of approximate areas between column line 1 through 16 and column lines A through G, column lines 1 through 5 and column lines $G$ through $L$, and the electrical equipment room located between column lines 12.1 and 15.5 and column line $\mathrm{G}$ through $\mathrm{H}$.

The inactive portion of the building is for the most part not used, except storage of material at the face of the reactor. Most of the stored material is in wood crates.

Special hazards consist of radiation, radioactive contamination, and plutonium fuel storage in the basin.

The Life Safety Code requires emergency lighting and exit signs. There are no deficiencies with respect to the exit signs, but the emergency lighting is inadequate according to NFPA 101. There are several work packages (JCS $1 \mathrm{~N}-92-00304 / \mathrm{S}$, 1N-93$00076 / \mathrm{W}$, and $1 \mathrm{~K}-94-00050 / \mathrm{W}$ ) to upgrade the emergency lighting throughout $105 \mathrm{KW}$. The number of exits, travel distances, exit width and direction of door swing is adequate with respect to the Life Safety Code.

\subsubsection{Fire Protection Features}

Part of the active portions of the 0 -ft, 0 -in. level are provided with automatic sprinkler protection supplied by a 4-in. connection to the 8-in. service water main in Corridor 5. A vane-type water flow switch is provided in the 4-in. line.

Portable fire extinguishers are located throughout the active areas and in some deactivated areas of the facility. There are five manual pull boxes in the facility.

The control room and transformer vault, in the inactive portion of the building, are provided with eight Fenwal heat detectors. Heat detector, manual pull, and water flow alarms are transmitted to the HFD via the RFAR system Box 1270.

Facility Pre-Fire Plans exist with the most recent revision being issued in 1993 and were scheduled to be revised in August 1994.

\subsubsection{Fire Barriers}

When the facility was constructed in the early 1950 s there were no identified fire barriers. Based upon the Fire Barrier Evaluation of the Wall Between Spent Nuclear Fuel Storage Basins and Reactor Areas, 105KE and 105KW (WHC 1994b), the barrier that separates the active areas from the D\&D areas is required to have a 2-hr fire resistance rating to divide the facility into two separate fire areas. This report identifies the recommended upgrades to qualify this barrier as an equivalent 2 - $\mathrm{hr}$ fire resistive barrier. 


\subsubsection{Fire Suppression Systems}

For strict compliance with DOE Order 5480.7A, the entire facility is required to have an automatic suppression system if the MPFL is determined (via FHA calculations) to be greater than $\$ 1$ million. If an FHA determines the D\&D areas to have an MPFL of less than $\$ 1$ million and the fire barrier that separates the active areas from the D\&D areas is upgraded to a minimum of 2-hour fire resistance rating, then the only area required to be upgraded with a complete automatic suppression system will be the active areas. The office area is partially sprinklered, but the basin area is not. Additional sprinklers are required in the office areas, the basement below the office, and in the basin area to be in compliance with DOE Order 5480.7A.

\subsubsection{Fire Alarm and Detection Systems}

The current fire alarm system in the facility complies with the requirements of DOE Order 5480.7A and NFPA with the exception that the initiating, and indicating circuits are not supervised as specified in NFPA 72.

\subsubsection{Housekeeping}

Housekeeping was very good in the personnel support areas. The area had ongoing activities taking place in it, but transient combustibles were kept low. Housekeeping was very good in the basins area with almost no transient combustibles present. Stored material in wood crates was located by the reactor face in the inactive portion of the facility.

\subsection{SWTTCHING STATION 151K}

\subsubsection{Construction}

The switching station is located approximately $100 \mathrm{ft}$ southeast of $1717 \mathrm{~K}$ and has a restricted access due to a security fence. All equipment is located outdoors and is a gravel area where the vegetation is controlled. Tumble weeds are kept out of the area by the security fencing.

\subsubsection{Occupancy/Life Safety Features}

The switching station is normally unoccupied unless maintenance of the equipment is being performed. Equipment within the security fence is electrical distribution equipment and a three-phase breaker.

There are no specific Life Safety Code requirements for an outside switching station. The security fence is normally locked restricting access. The individual that enters the area will have a key and will usually leave the entry gate open while working in the area. 


\subsubsection{Fire Protection Features}

There are no fire suppression or fire detection systems provided for the equipment. The oil-filled transformers are not mounted on bases that have sufficient oil containment features, but the entire switching station yard is covered with gravel.

\subsubsection{Fire Barriers}

There are no fire barrier requirements to separate the equipment within the switching station. Building $1717 \mathrm{~K}$ is located northwest of the switching station, but due to the separation distance between the equipment and the building (approximately $140 \mathrm{ft}$ ), there is no severe exposure problem present.

\subsubsection{Fire Suppression Systems}

A fire suppression system is not required for this exterior equipment unless there is an exposure concern to an adjacent building.

\subsubsection{Fire Alarm and Detection Systems}

A fire detection system is not required for this exterior equipment.

\subsubsection{Housekeeping}

Housekeeping within the confines of the fenced area is well maintained and free from combustibles and tumble weeds.

\subsection{SUBSTATION 151KE}

\subsubsection{Construction}

The substation is located east of $165 \mathrm{KE} / 190 \mathrm{KE}$ and has a restricted access due to a security fence. All equipment is located outdoors in a graveled area where the vegetation is controlled. Tumble weeds are kept out of the area by the security fencing.

\subsubsection{Occupancy/Life Safety Features}

The substation is normally unoccupied unless maintenance of the equipment is being performed. Equipment within the security fence is electrical distribution equipment consisting of six oil-filled transformers and four three-phase breakers. Four of the six oil-filled transformers are located $15 \mathrm{ft}$ east of the $165 \mathrm{KE}$.

No specific Life Safety Code requirements exit for an outside substation. The security fence is normally locked restricting access. The individual that enters the area will have a key and will usually leave the entry gate open while working in the area. 


\subsubsection{Fire Protection Features}

There are no fire suppression or fire detection systems provided for the equipment. The oil-filled transformers are not mounted on bases that have sufficient oil containment features, but the entire substation yard is covered with gravel.

\subsubsection{Fire Barriers}

There are no fire barrier requirements to separate the equipment within the substation. Building $165 \mathrm{KE} / 190 \mathrm{KE}$ is located west of the substation. Due to the separation distance between the equipment and the building, the substantial noncombustible construction of Building $165 \mathrm{KE}$ exterior walls, the shutters on the inside of the building protecting the ventilation openings, the set back from the exterior wall of equipment inside the building, and the steel equipment cabinets, there is not an exposure problem present.

\subsubsection{Fire Suppression Systems}

Fire suppression is not required for this exterior equipment unless there is an exposure concern to an adjacent building.

\subsubsection{Fire Alarm and Detection Systems}

A fire detection system is not required for this exterior equipment.

\subsubsection{Housekreeping}

The fenced area is well maintained and free from combustibles and tumbleweeds.

\subsection{SUBSTATION 151KW}

\subsubsection{Construction}

The substation is located east of $165 \mathrm{KW} / 190 \mathrm{KW}$ and has a restricted access due to a security fence. All equipment is located outdoors in a graveled area where the vegetation is controlled. Tumble weeds are kept out of the area by the security fencing. =

\subsubsection{Occupancy/Life Safety Features}

The substation is normally unoccupied unless maintenance of the equipment is being performed. Equipment within the security fence is electrical distribution apparatus consisting of six oil-filled transformers and four three-phase breakers.

There are no specific Life Safety Code requirements for an outside substation. The security fence is normally locked restricting access. The individual that enters the area will have a key and will usually leave the entry gate open while working in the area. 


\subsubsection{Fire Protection Features}

There are no fire suppression or fire detection systems provided for the equipment. The oil-filled transformers are not mounted on bases that have sufficient oil containment features, but the entire substation yard is covered with gravel.

\subsubsection{Fire Barriers}

There are no fire barrier requirements to separate the equipment within the substation. Building $165 \mathrm{KW} / 190 \mathrm{KW}$ is located west of the substation. Due to the separation distance between the equipment and the building, the substantial noncombustible construction of Building $165 \mathrm{KW}$ exterior walls, the robust shutters on the inside of the building protecting the ventilation openings, the set back of equipment inside the building from the exterior wall, and the steel equipment cabinets, there is not an exposure problem present.

\subsubsection{Fire Suppression Systems}

A fire suppression system is not required for this exterior equipment unless there is an exposure concern to an adjacent building.

\subsubsection{Fire Alarm and Detection Systems}

A fire detection system is not required for this exterior equipment.

\subsubsection{Housekeeping} weeds.

The fenced area is well maintained and free from combustibles and tumble

\subsection{BUILDING 165KE}

\subsubsection{Construction}

Building $165 \mathrm{KE}$ is a $43,000 \mathrm{ft}^{2}$ Power Control Building constructed with fire resistant materials as a bomb resistant shelter. Floors are reinforced concrete. Fourteen-in.-dia. concrete filled steel columns support a 18-in.-thick reinforced concrete ceiling and the 4-ply asphalt and gravel roof. Reinforced concrete exterior walls are windowless. Interior walls are reinforced concrete, concrete block, or cement asbestos board on wood studs. Interior surfaces are finished with paint. A reinforced concrete tunnel in the basement (167K) connects this building to $165 \mathrm{KW}$ and the tunnel is a cross tie tunnel for cable trays and miscellaneous piping. There are no qualified fire barriers and the facility consists of one fire area.

\subsubsection{Occupancy/Life Safety Features}

The 165KE Building switchgear room provides electrical power. The rest of the building houses valves, pipes, an unused control room, and an unused power plant. Occupancy of the facility is classified as a Special Purpose Industrial Occupancy according to the Life Safety Code. 
The Life Safety Code requires emergency lighting and exit signs. There are no deficiencies with respect to the exit signs, but the emergency lighting is inadequate with regard to NFPA 101. There are several work packages (JCS 1N-92-00305/S, \& 1N-93$00103 / \mathrm{W}$ ) to upgrade the emergency lighting throughout $165 \mathrm{KE}$. The facility is normally unoccupied unless maintenance is being performed on the switchgear or the piping in the building. Number of exits, travel distances, exit width and direction of door swing has no noted deficiencies as specified in Chapter 28 of the Life Safety Code.

\subsubsection{Fire Protection Features}

The $165 \mathrm{KE}$ Building is not provided with automatic sprinkler protection. The switchgear room is equipped with heat detectors on the ceiling and manual pull stations at the exits that transmit an alarm directly to the HFD via the RFAR system.

A Facility Pre-Fire Plan exists with the most recent revision being issued in June 1989 and was scheduled to be revised in June 1994. While the Pre-Fire Plan is overdue for updating, the information in the plan is up-to-date.

\subsubsection{Fire Barriers}

When the facility was constructed in the early 1950 s there were no identified fire barriers installed nor were any required. Both $165 \mathrm{KE}$ and $190 \mathrm{KE}$ were built as industrial occupancies and no fire barriers were required at the time of construction. The barrier that separates the valve room from the office/corridor area is constructed of reinforced concrete of substantial thickness. This barrier is not a qualified fire barrier; however, the construction of this wall is comparable to that of a $2-\mathrm{hr}$ fire resistive barrier. It is expected that this barrier will provide fire separation between the two areas provided the doors are closed. The south barrier that separates $165 \mathrm{KE}$ from $190 \mathrm{KE}$ is also substantial construction of reinforced concrete that is also expected to provide a fire separation between the two buildings although the barrier is not a fire barrier. The separation distance between the east wall of the building and the four transformers in the $151 \mathrm{KE}$ switchyard is $15 \mathrm{ft}$. According to strict compliance of FM Loss Prevention Data Sheet 5-4, a fire barrier, greater separation distance, or a water spray system for the transformers should be provided to limit the exposure since they are $15 \mathrm{ft}$ east of the building.

\subsubsection{Fire Suppression Systems}

DOE Order 5480.7A requires that any facility having an MPFL greater than $\$ 1$ million shall be provided with an automatic suppression system. Building replacement cost according to the RL Property System is $\$ 7,294,702$. An FHA is required to determine the MPFL. The combustible loading in the building is very low and primarily consists of the switchgear in the east portion of the building. A credible fire in this facility is not expected to result in a total loss of the facility. However, it would be possible to lose a large portion of the switchgear that might have a value greater than $\$ 1$ million. This switchgear is not "vital" to the operation of the $100 \mathrm{~K}$ Area and an unacceptable delay in the operations of $100 \mathrm{~K}$ Area is not expected if this switchgear is lost. If the FHA indicates an MPFL for this facility to be greater than $\$ 1$ million, then automatic suppression is required as specified in DOE Order 5480.7A. 


\subsubsection{Fire Alarm and Detection Systems}

The unoccupied facility is not provided with manual pull stations, but is provided with occupant notification bells throughout the facility and heat detectors in the switchgear room. These heat detectors are wired via Romex. Because the low heat release rates of the combustible material present (primarily wire insulation), the heat detectors provide only a very limited amount of fire protection. There is a work package (JCS 1K-94-00097/W) that will replace the wiring according to the requirements of NFPA 72. Manual pull stations and occupant notification bells are not required since this special purpose industrial occupancy is not normally occupied (NFPA 101, Section 283.4.1, Exception).

\subsubsection{Houselkeeping}

Housekeeping was very good. The only transient combustibles noted were many bags of overalls in the center hall on the ground floor. A tour of the power plant was not made due to an asbestos barricade at the entrance door.

\subsection{BUTLDNG 165KW}

\subsubsection{Construction}

Building $165 \mathrm{KW}$ is a $43,000 \mathrm{ft} 2$ Power Control Building constructed of fire resistant materials as a bomb resistant shelter. Floors are reinforced concrete. Fourteen-in.-dia. concrete filled steel columns support an 18-in.-thick reinforced concrete ceiling and the 4-ply asphalt and gravel roof. Reinforced concrete exterior walls are windowless. The roof is 4-ply asphalt and gravel. Interior walls are reinforced concrete, concrete block, or cement asbestos board on wood studs. Interior surfaces are finished with paint. A reinforced concrete tunnel in the basement (167K) connects this building to $165 \mathrm{KE}$ and the tunnel is a cross tie tunnel for cable trays and miscellaneous piping. There are no qualified fire barriers, thus only one fire area.

\subsubsection{Occupancy/Life Safety Features}

The 165KW Building switchgear room provides electrical power. The rest of the building houses valves, pipes, an unused control room, and an unused power plant. This facility is classified as a Special Purpose Industrial Occupancy in accordance with the Life Safety Code.

The Life Safety Code requires emergency lighting and exit signs. There are no deficiencies with respect to the exit signs, but the emergency is inadequate with respect to NFPA 101. The facility is normally unoccupied unless maintenance is being performed on the switchgear or the piping in the building. The number of exits, travel distances, exit width and direction of door swing has no noted deficiencies as specified in the Life Safety Code. 


\subsubsection{Fire Protection Features}

The 165KE Building is not provided with automatic sprinkler protection. The switchgear room is equipped with heat detectors on the ceiling and manual pull stations at the exits that transmit an alarm directly to the HFD via RFAR box 1280 .

A Facility Pre-Fire Plan exists with the most recent revision being issued in July 1994 and is scheduled to be revised in July 1999. This Pre-Fire Plan is current and contains the most up-to-date information.

\subsubsection{Fire Barriers}

When the facility was constructed in the early 1950s there were no identified fire barriers installed nor were there any required. Both $165 \mathrm{KW}$ and $190 \mathrm{KW}$ were built as industrial occupancies and no fire barriers were required at the time of construction. The barrier that separates the valve room from the office/corridor area is constructed of reinforced concrete of substantial thickness. This barrier is not a qualified fire barrier; however, the construction of this wall is comparable to that of a 2-hr fire resistive barrier. It is expected that this barrier will provide fire separation between the two areas provided the doors are closed. The south barrier that separates $165 \mathrm{KW}$ from $190 \mathrm{KW}$ is also substantial construction of reinforced concrete that is also expected to provide a fire separation between the two buildings although the barrier is not a qualified fire barrier. Separation distance between the east wall of the building and the four transformers in the $151 \mathrm{KW}$ switchyard is $15 \mathrm{ft}$. In accordance with strict compliance of FM Loss Prevention Data Sheet 5-4, a fire barrier, greater separation distance, or a water spray system for the transformers should be provided to limit the exposure since they are $15 \mathrm{ft}$ east of the building.

\subsubsection{Fire Suppression Systems}

DOE Order 5480.7A requires that any facility having an MPFL greater than $\$ 1$ million shall be provided with an automatic suppression system. The building replacement cost in accordance with the RL Property System is \$8,452,569. An FHA is required to determine the MPFL. The combustible loading in the building is very low and primarily consists of the switchgear in the east portion of the building. A credible fire in this facility is not expected to result in a total loss of the facility. However, it would be possible to lose a large portion of the switchgear that might have a value greater than \$1 million. This switchgear is not "vital" to the operation of the 100K Area and an unacceptable delay in the operations of 100K Area is not expected if this switchgear is lost. If the FHA indicates an MPFL for this facility to be greater than $\$ 1$ million, then automatic suppression is required with respect to DOE Order 5480.7A.

\subsubsection{Fire Alarm and Detection Systems}

The unoccupied facility is not provided with manual pull stations, but is provided with occupant notification bells throughout the facility and heat detectors in the switchgear room. These heat detectors are wired via romex. Because the low heat release rates of the combustible material present (primarily wire insulation), the heat detectors provide only a very limited amount of fire protection. Manual pull stations and 
occupant notification bells are not required since this special purpose industrial occupancy is not normally occupied (NFPA 101, Section 28-3.4.1, Exception).

\subsubsection{Housekeeping}

Housekeeping was very good. A tour of the power plant was not made because we could not gain access due to asbestos contamination in this area.

\subsection{BUILDING/TUNNEL 167K}

\subsubsection{Construction}

The cross tie tunnel is located below grade and connects the basements of $165 \mathrm{KE}$ and $165 \mathrm{KW}$. The tunnel is constructed of reinforced concrete.

\subsubsection{Occupancy/Life Safety Features}

This normally unoccupied tunnel requires radio communication for all persons entering the tunnel due to possible exposure to chlorine gas in case of a chlorine leak. The tunnel contains miscellaneous piping and six open cable trays measuring $12 \mathrm{in.}$ by 3 in. that are approximately 40 percent filled.

The tunnel is not normally occupied. A facility of this type that is not occupied has no Life Safety Code requirements.

\subsubsection{Fire Protection Features}

There are no fire protection features provided in this tunnel.

\subsubsection{Fire Barriers}

No fire barriers are required in this tunnel.

\subsubsection{Fire Suppression Systems}

Fire suppression systems are not required in this tunnel.

\subsubsection{Fire Alarm and Detection Systems}

No fire alarm and detection systems are required in this tunnel.

\subsubsection{Housekeeping}

The tunnel is very clean and contains no transient combustibles. Cable insulation in the cable trays is the only combustible in the tunnel. 


\subsection{BUIIDING 183KE}

\subsubsection{Construction}

The 183KE Building is a single story structure with a basement having a total floor space of $18,734 \mathrm{ft}^{2}$ per floor. Exterior walls are constructed of a steel frame covered by transite. The roof is a 4-ply tar and gravel built-up roof covering on 2-in. of foam glass insulation supported by steel frame and corrugated asbestos cement roofing panels. The building has two levels separated by a reinforced concrete floor. A reinforced concrete tunnel from the basement of Building $183 \mathrm{KE}$ to Building $190 \mathrm{KE}$ provides access for water distribution piping and valves.

\subsubsection{Occupancy/Life Safety Features}

Occupancy classification for this facility is a business occupancy according to the UBC and industrial as specified in the Life Safety Code. The building consists of a headhouse/chlorine vault, two lime houses and a filter plant for the reactor water. Use of the facility is currently to chlorinate and filter water received from the Columbia River. The original chlorination equipment and the vaults are decommissioned. Deactivated electrical equipment and pumps, which are no longer in use, are housed in the basement. There are some office areas on the first floor that house Operations Support and Health Physics personnel.

The Life Safety Code requires emergency lighting and exit signs. Deficiencies with respect to the exit signs and the emergency lighting were observed. There is a work package (JCS $1 \mathrm{~N}-92-00306 / \mathrm{S})$ to add emergency lights to the facility with respect to NFPA 101. Number of exits, travel distances, exit width and direction of door swing has no noted deficiencies according to the Life Safety Code.

\subsubsection{Fire Protection Features}

The facility is not provided with an automatic suppression or automatic detection system. A sufficient number of adequately sized portable fire extinguishers are located throughout the facility. There are no fire barriers in the facility. The entire building, basement and first floor included, is one fire area. There are two, oil-filled transformers located $18 \mathrm{ft}$ east of the building. These transformers are not provided with an automatic suppression system and are not separated with fire resistive construction in compliance with the recommendations of FM Loss Prevention Data Sheet 5-4.

The Pre-Fire Plan is not current because the most recent Pre-Fire Plan for this facility is dated October 1988 and was to be updated every five years. Although the PreFire Plan was not updated by October 1993, the information in the October 1988 Pre-Fire Plan is current.

\subsubsection{Fire Barriers}

When the facility was constructed in the early 1950s there were no identified fire barriers installed nor were there any required. This facility is classified as an industrial occupancy and no fire barriers were required at the time of construction. Two $500 \mathrm{kVA}$ oil-filled transformers are located $18 \mathrm{ft}$ east of the building. The building is 
non-combustible construction, but FM Loss Prevention Data Sheet requires a separation distance of $25 \mathrm{ft}$, therefore, these transformers are identified as an exposure concern.

\subsubsection{Fire Suppression Systems}

DOE Order 5480.7A requires that any facility having an MPFL greater than $\$ 1$ million be provided with an automatic suppression system. The building replacement cost according to the RL Property System is $\$ 6,050,703$. An FHA is required to determine the MPFL. The combustible loading in the building is very low. A credible fire in this facility is not expected to result in a total loss of the facility. However, it would be possible to have a fire loss exceed $\$ 1$ million. If the FHA indicates an MPFL for this facility to be greater than $\$ 1$ million, then automatic suppression is required in accordance with DOE Order 5480.7A.

\subsubsection{Fire Alarm and Detection System}

This facility is not provided with manual pull stations or occupant notification bells. Manual pull stations and occupant notification bells are not required since this industrial occupancy if the occupant load is less than ten.

\subsubsection{Housekeeping}

The housekeeping in this building is good. Combustible loading throughout the facility was low.

\subsection{BUILDING 190KE}

\subsubsection{Construction}

The 190KE Building is a noncombustible $52,500 \mathrm{ft}^{2}$ single story building including a basement. Exterior walls of the building are constructed of a steel frame with transite siding. The roof is a 4-ply tar and gravel built-up roof covering on 2 in. of foam glass insulation supported by steel frame and corrugated asbestos cement roofing panels. The building has two levels separated by a reinforced concrete floor. There are no interior walls.

\subsubsection{Occupancy/Life Safety Features}

Building 190KE houses service water pumps and is currently being used general storage. Occupancy classification according to the UBC and the Life Safety Code is a mixed occupancy of storage and industrial. Current storage consists of materials purchased to support work packages, several approved flammable liquids cabinets, and excess D\&D equipment. The industrial occupancy consists of operational service water pumps that are used to supply service water to the 100K Area Facilities. The proposed occupancy is to install office space, a maintenance shop, and all other areas will be used for storage. Existing service water pumps are to remain in service.

The facility is provided with two exits and the travel distances comply with the Life Safety Code. There are no exit signs, but there are a limited number of batterypowered emergency lights. 


\subsubsection{Fire Protection Features}

The 190KE Building is not equipped with an automatic suppression or automatic detection system. However, when the new maintenance shop is installed in this facility, the existing building and the new maintenance shop will be provided with automatic sprinklers throughout. Manual pull stations and occupant notification are also proposed as part of this maintenance shop project.

A Pre-Fire Plan was prepared in June 1989 and was scheduled for revision in June 1994. The June 1989 Pre-Fire Plan identifies the hazards present and describes the mitigation features for manual fire suppression. No special hazards were present.

\subsubsection{Fire Barriers}

When the facility was constructed in the early 1950 s there were no identified fire barriers installed nor were any required. This facility is classified as a mixed occupancy, and no fire barriers were required at the time of construction. The barrier that separates this building and $165 \mathrm{KE}$ is constructed of reinforced concrete of substantial thickness and, with the doors closed, is expected to provide a minimum of 2-hr fire resistance rating.

\subsubsection{Fire Suppression Systems}

Building 190KE is not provided with a fire suppression system. DOE Order 5480.7A requires that any facility having an MPFL greater than $\$ 1$ million be provided with an automatic suppression system. The building replacement cost according to the RL Property System is $\$ 6,019,704$. An FHA is required to determine the MPFL. The combustible loading in the building is low to moderate with the exception to the flammable and combustible liquids that are stored in the northeast corner of the building. A credible fire in this facility is not expected to result in a total loss of the facility. However, it would be possible to lose a large portion of storage media that might have a value greater than $\$ 1$ million. If the FHA shows an MPFL for this facility to be greater than $\$ 1$ million, then automatic suppression is required according to DOE Order 5480.7A.

\subsubsection{Fire Alarm and Detection Systems}

This facility is not provided with manual pull stations or occupant notification bells. Manual pull stations and occupant notification bells are not required if the industrial occupancy has an occupant load less than 100 at the level of exit discharge or 25 above or below the level of exit discharge (NFPA 101, Section 28-3.4.1, Exception) and if the storage is classified as "low" with respect to the Life Safety Code. A determination of the storage must be made before using this exception. If the storage is not "low," then the exception cannot be used.

\subsubsection{Housekeeping}

There were excessive flammable and combustible liquids not stored in approved flammable liquids cabinets in the northeast corner of the building. There were at least 
WHC-SD-W405-PD-002, Rev. 0

seven flammable liquids cabinets within a $100-\mathrm{ft}$ radius that exceeds the limitations of NFPA 30 . The storage of other combustible materials were acceptable and stored in an orderly arrangement.

\subsection{BUILDING 190KW}

\subsubsection{Construction}

Building $190 \mathrm{KW}$ is a noncombustible $52,500 \mathrm{ft}^{2}$ single story building including a basement. Exterior walls of the building are constructed of a steel frame with transite siding. The roof is a 4-ply tar and gravel built-up roof covering on 2 in. of foam glass supported by steel frame and corrugated asbestos cement roofing. The building has two levels separated by a reinforced concrete floor. There are no interior walls.

\subsubsection{Occupancy/Life Safety Features}

Building $190 \mathrm{KW}$ houses six 10,000 horsepower reactor cooling water pumps, service water pumps and general storage. Occupancy classification according to the UBC and the Life Safety Code is a mixed occupancy of storage and industrial. The current storage consists of empty fuel canisters in cardboard boxes on wooden pallets, several approved flammable liquids cabinets, zirconium tubes, and excess D\&D equipment storage. The industrial occupancy consists of abandoned in place reactor cooling water and service water pumps.

The facility is provided with two exits and the travel distances comply with the Life Safety Code. There are no exit signs, but there are a limited number of batterypowered emergency lights.

\subsubsection{Fire Protection Features}

Building $190 \mathrm{KW}$ Building is not equipped with an automatic suppression or automatic detection system.

A Pre-Fire Plan was prepared in June 1989 and was scheduled for revision in June 1994. The June 1989 Pre-Fire Plan identifies the hazards present and describes the mitigation features for manual fire suppression.

Combustible metal in the form of zirconium tubes is a special fire hazard in this facility. Zirconium, in massive form, can withstand extremely high temperatures without igniting. Only in dust form is this combustible metal a problem.

\subsubsection{Fire Barriers}

When the facility was constructed in the early 1950s there were no identified fire barriers installed nor were they required. This facility is classified as a mixed occupancy and no fire barriers were required at the time of construction. The barrier that separates the this building and $165 \mathrm{KW}$ is constructed of reinforced concrete of substantial thickness and, with the doors closed, is expected to provide a minimum of 2-hr fire resistance rating. 


\subsubsection{Fire Suppression Systems}

Building $190 \mathrm{KW}$ is not provided with a fire suppression system. DOE Order $5480.7 \mathrm{~A}$ requires that any facility having an MPFL greater than $\$ 1$ million be provided with an automatic suppression system. The building replacement cost with respect to the RL Property System is $\$ 6,019,704$. An FHA is required to determine the MPFL. The combustible loading in the building is low to moderate. A credible fire in this facility is not expected to result in a total loss of the facility. However, it would be possible to lose a large portion of storage media that might have a value greater than $\$ 1$ million. If the FHA indicates an MPFL for this facility to be greater than $\$ 1$ million, then automatic suppression is required as specified in DOE Order 5480.7A.

\subsubsection{Fire Alarm and Detection Systems}

This facility is not provided with manual pull stations or occupant notification bells. Manual pull stations and occupant notification bells are not required if the industrial occupancy has an occupant load less than 100 at the level of exit discharge or 25 above or below the level of exit discharge (NFPA 101, Section 28-3.4.1, Exception) and if the storage is low with respect to the Life Safety Code.

\subsubsection{Housekeeping}

Storage of combustible materials were acceptable and arranged in an orderly arrangement.

\subsection{BUILDING 1706KE/KEL}

\subsubsection{Construction}

Building $1706 \mathrm{KE}$ is located $19 \mathrm{ft}$ south of Building $105 \mathrm{KE}$ and $30 \mathrm{ft}$ south of Building $1706 \mathrm{KEL}$. Building $1706 \mathrm{KE} / \mathrm{KEL}$ is $170 \mathrm{ft}$ by $95 \mathrm{ft}$ with one story and two basement levels. The first basement level (elevation -13-ft, 0 -in.) connects to the basement of 1706KER. The floors are reinforced concrete and the walls are steel beams and concrete blocks with transite as the exterior siding. The roof is a built-up tar and gravel covering supported by steel beams.

\subsubsection{Occupancy/Life Safety Features}

Building $1706 \mathrm{KE} / \mathrm{KEL}$ houses laboratory facilities to support the $100 \mathrm{~K}$ Area operation. Occupancy classification according to the Life Safety Code and the UBC is business. There are many different kinds of chemicals and acids in both sections of the building. All flammable and combustible liquids that are used for the laboratory operations are stored in UL Listed Flammable Liquid cabinets or containers. Hexane is used in the Hot Lab in 1706KEL for decontamination and cleaning. However, all hexane is drained from the cleaning apparatus and is stored in approved flammable liquid cabinets.

This building normally has an occupant load of less than ten people. There are seven exits out of the building. Travel distances, number of exits, exit width, and direction of door swing has no noted deficiencies as specified in the Life Safety Code. 


\subsubsection{Fire Protection Features}

The building is not provided with an automatic suppression system, but is provided with a complete alarm and detection system. Manual pull stations are provided at all primary exit doors except one in 1706KEL. Heat detectors are provided in all areas of all levels. Alarms are transmitted to HFD via the RFAR system. There are sufficient number of adequately sized fire extinguishers located throughout the facility. Fire hydrant \#6 is located $250 \mathrm{ft}$ east of the facility.

The Pre-Fire Plan is not current because the most recent Pre-Fire Plan for this facility is dated August 1990 and was to be updated every three years. Although the PreFire Plan was not updated by August 1993 and is overdue, the information in the August 1990 Pre-Fire Plan is current.

There are no severe fire exposures to building $1706 \mathrm{KE} / \mathrm{KEL}$ according to the calculations of NFPA 80A.

\subsubsection{Fire Barriers}

When this facility was constructed there were no fire barriers required nor were any built into it. The building has been added on to several times over the years.

\subsubsection{Fire Suppression Systems}

This building was constructed without sprinklers. The total replacement cost of the combined buildings and contents is $\$ 4,890,015$. An FHA is required to determine the MPFL. Assuming the MPFL exceeds $\$ 1$ million, DOE Order 5480.7A will require sprinklers throughout the structure including the two basements.

\subsubsection{Fire Alarm and Detection Systems}

The building is equipped with heat detectors and occupant notification bells through out that are controlled by a Pyrotronics System 3 fire alarm panel. All except one of the seven exits are equipped with manual pull stations.

\subsubsection{Housekeeping}

Combustible loading in the facility is minimal. Housekeeping near the northeast exit door onto the loading dock needs improvement. The area adjacent to the door is used for the storage of excess equipment and is obstructing the exit passageway.

\subsection{BUIIDING 1706KRR}

\subsubsection{Construction}

Building 1706KER is located $30 \mathrm{ft}$ north of Building $1706 \mathrm{KE} / \mathrm{KEL}$. The building is $103 \mathrm{ft}$ by $30 \mathrm{ft}$ with one story and a basement that connects to the basement of $1706 \mathrm{KE} / \mathrm{KEL}$. Floors are reinforced concrete and walls are steel beams with transite as 
the exterior siding. The roof is a built-up tar and gravel covering supported by steel beams.

\subsubsection{Occupancy/Life Safety Features}

Building 1706KER is classified as an industrial occupancy according to the Life Safety Code and a business occupancy according to the UBC. The ground floor is unoccupied and contains two fan/filter units, a small miscellaneous storage area, and three office areas that are currently used for storage. The unoccupied basement area consists of four reactor test cells, a decontamination room and a shop area that are radiation zones. The only area that was accessed in the basement was the south corridor. All equipment in the facility has been decommissioned except for some of the switchgear that is used to operate the some of the fans for the facility. $1706 \mathrm{KE}$.

Building 1706KER is unoccupied and connected at the basement level with

\subsubsection{Fire Protection Features}

The building is not provided with an automatic suppression system, but is provided with a limited alarm and detection system. One manual pull station is provided at the door from 1706KER into $1706 \mathrm{KE} / \mathrm{KEL}$, and there are seven heat detectors in the facility. One detector is in the southwest corner of the ground floor and six are in the shop areas and south corridor of the basement level. There are fire extinguishers located throughout the facility. Fire hydrants \#6 and \#8 are both located within $500 \mathrm{ft}$ of the facility, one north and one southeast of the facility.

The Pre-Fire Plan is not current because the most recent Pre-Fire Plan for this facility is dated October 1984 and was to be updated every five years which would have been October 1989. Although the Pre-Fire Plan has not been updated for 10 years the information is current. There are no severe fire exposures to building 1706KER.

\subsubsection{Fire Barriers}

When the structure was built, no fire barriers were required, and there currently are none provided in the facility.

\subsubsection{Fire Suppression Systems}

Building 1706KER was constructed without sprinklers. Total replacement cost of the structure is carried as $\$ \mathbf{2 , 4 5 2 , 1 7 6}$. An FHA is required to determine the MPFL. Assuming the MPFL is equal to the replacement cost, DOE Order 5480.7A requires fire sprinklers through out the facility including the basement. Note that since part of the basement is a radiation area, there would be increased construction costs for installing automatic fire suppression sprinklers.

\subsubsection{Fire Alarm and Detection Systems}

The basement of the building is equipped with six heat detectors and the main level has one heat detector in the chemical/miscellaneous storage area. 


\subsubsection{Housekeeping}

The housekeeping in the facility is maintained well for a facility that is primarily decommissioned and unoccupied.

\subsection{BUIIDING 1717K}

\subsubsection{Construction}

Building $1717 \mathrm{~K}$ is a single story, $10,800 \mathrm{ft}^{2}$, noncombustible facility. Floors are reinforced concrete and walls are steel beams with transite as the exterior siding. The roof is a built-up tar and gravel covering supported by steel beams. The interior partition consists of concrete block, masonry or gypsum board.

\subsubsection{Occupancy/Life Safety Features}

Building $1717 \mathrm{~K}$ is a mixed occupancy of business and industrial according to the Life Safety Code. The building provides office space for $\mathrm{K}$ Area Operations, Riggers, and Maintenance personnel. It also provides shop space for electrical and mechanical maintenance activities, instrument technicians, and a storage area for the tool crib.

Travel distances, the four exits, exit width, and direction of door swing has no noted deficiencies. The instrument shop exit and west exit were missing exit signs.

\subsubsection{Fire Protection Features}

The building is provided with an automatic wet pipe sprinkler system. Three manual pull stations, the pressure switch for the automatic sprinkler system, alarm bells, tamper switch on the PIV and RFAR Box 1260 comprise the fire alarm system. The RFAR transmits the fire alarm signal to the fire dispatch center located in the 600 Area Fire Station. Sufficient number of adequately sized fire extinguishers are located throughout and fire hydrant \#13 is located $55 \mathrm{ft}$ southeast of the building.

A Pre-Fire Plan for the facility was developed in November 1989 and is current with respect to the required operations within the building, but is due to be updated in . = 1994. There are no severe exposure concerns for this facility.

\subsubsection{Fire Barriers}

The building was not required to have any fire barriers at the time of construction and none were constructed.

\subsubsection{Fire Suppression Systems}

The building has fire sprinklers throughout. Some rooms have an open grid type ceiling below the fire sprinklers. There appears to be sufficient ratio of open area to total area in the grid with respect to NFPA 13 to provide adequate sprinkler coverage. 


\subsubsection{Fire Alarm and Detection Systems}

Three manual pull stations (the east exit was missing a pull station), the pressure switch for the automatic sprinkler system, alarm bells, tamper switch on the PIV and RFAR Box 1260 comprise the fire alarm system. The fire alarm bell circuit is not supervised according to NFPA 72.

\subsubsection{Housekeeping}

The housekeeping throughout the facility was good for a maintenance shop area. Maintenance areas were neat and orderly with all compressed gas cylinders properly supported and the limited amount of flammable and combustible liquids were stored in approved containers. 


\subsection{CONSULTANTS EVALUATIONS/RECOMMENDATIONS}

\subsection{DAVID GESSERTS EVALUATION/RECOMMENDATIONS}

The following observations and recommendations take into consideration the following factors:

- Life safety concerns,

- Providing cost effective solutions to complex problems,

- The limited remaining life of the $100 \mathrm{~K}$ Area facilities,

- Construction materials and type of construction,

- Number of building occupants,

- Available ignitions sources,

- Administrative controls, and

- Potential for the release of radioactive contamination.

There is no differentiation of recommendations between a 6 or 12-year remaining life. Additional fire protection measures may be warranted if the remaining life were 20 years or more. This is based on one-half the normal 40-year life of an industrial facility.

OBSERVATION: There is a need to inventory stored material and estimate the total amount of storage space required for the following areas:

- Material stored at the reactor faces in both $105 \mathrm{KE}$ and $105 \mathrm{KW}$.

- Material planned to be stored in the remodeled 190KE.

OBSERVATION: Random interviews with employees of the 100K Area Facilities indicated a general awareness of the appropriate actions expected in the event of a fire. However, there could be a stronger response by employees as to the exact actions expected by the management of the facility in the event of a fire.

OBSERVATION: All of the overdue 100K Area Facility Pre-Fire Plans should be updated. While no discrepancies were identified, it is a good practice to have a current Pre-Fire Plan on file at the HFD.

Recommended exemptions should be pursued only as long as the other recommendations are implemented for each building. Exemptions are based on risk compared to recognized industrial practice and the limited remaining life of the facility. Additional analysis should accompany the exemption request.

\subsubsection{Building 105KE}

The recommendations for Building $105 \mathrm{KE}$ are as follows:

1. The wall between the active side of the building and the D\&D side of the building should be upgraded to a 2-hr fire barrier. This will be a cost-effective way to minimize the possible fire challenge to the fuel storage basin. 
2. Complete the partial sprinkler system in the active side of the building that houses the support functions. This is a cost-effective way to minimize the possible fire challenge to the fuel storage basin.

3. Complete the work packages to upgrade the emergency lighting and exit signs in the active areas of the facility according to NFPA 101, Life Safety Code.

4. Remove all transient combustibles including material stored in wood crates at the face of the reactor from the D\&D side of the facility. The material should be properly disposed of or stored in a facility with automatic fire suppression. By removing the transient combustibles the intent of DOE Order 5480.7A paragraph 4.b. will be fulfilled.

5. Do not upgrade the fire alarm system to a supervised system. However, all electrical should be installed in compliance with the National Electric Code. Out-of-compliance electrical wiring creates a fire hazard by the very system that is designed to mitigate the consequences of fire. The existing electrical wiring for the fire alarm system is not in keeping with the best class protected class of industrial risk.

6. Do not install the sprinklers over the fuel storage basin. Due to very low permanent combustible loading, very low transient combustible loading, administrative controls on hot work, administrative controls on the buildup of transient combustible loading, the restricted access to this plant area, and the presence of water in the basin, sprinklers are not cost effective. Additionally this facility has a limited life of only 6 to 12 years.

7. Do not install fire sprinklers in the basement. This is an unoccupied area of the building with very low combustible loading and constructed of noncombustible materials. Installation of sprinklers in the basement would not sufficiently reduce the chance of fire and is not cost effective.

8. Apply for an exemption to the DOE Order 5480.7A requirement to install automatic fire sprinklers in the following areas:

- Fuel storage basin area assuming the MPFL exceeds $\$ 1$ million.

- Basement of the plant assuming the MPFL exceeds $\$ 1$ million.

- D\&D portion of the facility assuming the MPFL exceeds $\$ 1$ million.

\subsubsection{Building 105KW}

The recommendations for Building $105 \mathrm{KW}$ are as follows:

1. The wall between the active side of the building and the D\&D side of the building should be upgraded to a 2 -hr fire barrier. This will be a cost-effective way to minimize the possible fire challenge to the fuel storage basin. 
2. Complete the partial sprinkler system in the active side of the building that house the support functions. This is a cost-effective way to minimize the possible fire challenge to the fuel storage basin.

3. Complete the work packages to upgrade the emergency lighting and exit signs in the active areas of the facility according to NFPA 101, Life Safety Code.

4. Remove all transient combustibles including material stored in wood crates at the face of the reactor from the D\&D side of the facility. The material should be properly disposed of or stored in a facility with automatic fire suppression. By removing the transient combustibles the intent of DOE Order 5480.7A paragraph 4.b. will be fulfilled.

5. Do not upgrade the fire alarm system to a supervised system. However, all electrical should be installed as specified in the National Electric Code. Out of compliance electrical wiring creates a fire hazard by the very system that is designed to mitigate the consequences of fire. The existing electrical wiring for the fire alarm system is not in keeping with the best class protected class of industrial risk.

6. Do not install the sprinklers over the fuel storage basin. Due to very low permanent combustible loading, very low transient combustible loading, administrative controls on hot work, administrative controls on the buildup of transient combustible loading, the restricted access to this plant area, and the presence of water in the basin, sprinklers are not cost effective. Additionally this facility has a limited life of 6 or 12 years.

7. Do not install fire sprinklers in the basement. This is an unoccupied area of the building with very low combustible loading and constructed of noncombustible material. Installation of sprinklers in the basement would not sufficiently reduce the chance of fire and is not cost effective.

8. Do not install fire sprinklers under the standing seam metal roof over the built-up asphalt and gravel roof. Due the low chance of a fire in this unoccupied area, sprinklers are not cost effective.

9. Apply for an exemption to the DOE Order 5480.7A requirement to install fire sprinklers in the following areas:

- Fuel storage basin area assuming the MPFL exceeds $\$ 1$ million.

- Basement assuming the MPFL exceeds $\$ 1$ million.

- D\&D portion of the facility assuming the MPFL exceeds $\$ 1$ million.

- Under the standing seam metal roof over the built-up asphalt and gravel roof.

\subsubsection{Switching Station 151K}

No recommendations. The switching station yard is normally unoccupied and adequate maintenance is being done to keep out vegetation and tumble weeds. 


\subsubsection{Substation 151KE}

No recommendations. The substation yard is normally unoccupied and adequate maintenance is being done to keep out vegetation and tumble weeds.

\subsubsection{Substation 151KE}

No recommendations. The substation yard is normally unoccupied and adequate maintenance is being done to keep out vegetation and tumble weeds.

\subsubsection{Building 165KE}

1. Since there exists a reinforced concrete wall that offers substantial fire resistant between $165 \mathrm{KE}$ and $190 \mathrm{KE}$, the doors should be kept shut between the two buildings. Signs and/or administrative controls should be implemented to ensure the doors stay closed.

2. Shutters on the east side of the switchgear room should be kept closed to reduce the exposure hazard from the transformers on the outside of the building to the east. Signs and/or administrative controls should be implemented to ensure the shutters stay closed.

3. Do not install fire sprinklers. The building is unoccupied and has very low combustible loading. Sprinklers are not cost effective.

4. Do not upgrade the existing heat detectors to a supervised system. However, the wiring should be upgraded to the standards of the National Electric Code and NFPA 72. Out of compliance electrical wiring creates a fire hazard by the very system that is designed to mitigate the consequences of fire. The existing electrical wiring for the fire alarm system is not in keeping with the best class protected class of industrial risk. As an alternative, the heat detector system could be removed since they provide a very limited degree of fire protection due to the hazard present.

5. Apply for an exemption to DOE Order 5480.7A requirements for the installation of automatic fire sprinklers if the MPFL exceeds $\$ 1$ million.

\subsubsection{Building 165KW}

1. Since there exists a reinforced concrete wall that offers substantial fire resistant between $165 \mathrm{KW}$ and $190 \mathrm{KW}$, the doors should be kept shut between the two buildings. Signs and/or administrative controls should be implemented to insure the doors stay closed.

2. The shutters on the east side of the switchgear room should be kept closed to reduce the exposure hazard from the transformers on the outside of the building to the east. Signs and/or administrative controls should be implemented to insure the shutters stay closed. 
3. Do not install fire sprinklers. The building is unoccupied and has very low combustible loading. Sprinklers are not cost effective.

4. Do not upgrade the existing heat detectors to a supervised system. However, the wiring should be upgraded to the standards of the National Electric Code and NFPA 72. Out-of-compliance electrical wiring creates a fire hazard by the very system that is designed to mitigate the consequences of fire. The existing electrical wiring for the fire alarm system is not in keeping with the best class protected class of industrial risk. As an alternative, the heat detector system could be removed since they provide a very limited degree of fire protection due to the hazard present.

5. Apply for an exemption to DOE Order 5480.7A requirements for the installation of automatic fire suppression sprinklers, including the basement, if the MPFL exceeds $\$ 1$ million.

\subsubsection{Building/Tunnel 167K}

No recommendations. The tunnel is normally unoccupied and has very low combustible loading.

\subsubsection{Building 183KE}

1. If the normal number of occupants increase to 10 or more, install manual pull stations and occupant notification.

2. Do not install fire sprinklers. Due to the building construction and low combustible loading, fire sprinklers are not cost effective.

3. Apply for an exemption to DOE Order 5480.7A requirements for the installation of automatic fire suppression sprinklers, including the basement, if the MPFL exceeds $\$ 1$ million.

\subsubsection{Building 190KE}

1. If the building is to remain as is, all transient combustibles including storage should be removed from the building and properly disposed of or stored in a facility with automatic fire suppression. Totally noncombustible storage (no cardboard, wood, etc.) is satisfactory.

2. The door between $190 \mathrm{KE}$ and $165 \mathrm{KE}$ should be kept closed. Signs and/or administrative controls should be implemented to insure the doors stay closed.

3. If the building will house the proposed two-story office building within the building, maintenance shop, and storage, then all areas except the basement should be provided with automatic fire sprinklers, emergency lighting, manual pull stations, occupant notification, and exit signs. 
4. No storage shall be allowed in the basement. Do not install fire sprinklers in the basement. It is not cost effective to provide fire protection in an area that has little or no fuel and a limited remaining life.

5. If the building is to remain as is, then apply for an exemption to the DOE Order $5480.7 \mathrm{~A}$ requirement for the installation of automatic fire suppression sprinklers, including the basement, if the MPFL exceeds $\$ 1$ million.

6. If the building is to be upgraded, automatic fire suppression sprinklers should be installed on the main level. Apply for an exemption to the DOE Order 5480.7A requirement for the installation of automatic fire suppression sprinklers in the basement.

\subsubsection{Building 190KW}

1. If the building is to remain as is, all transient combustibles including storage should be removed from the building and properly disposed of or stored in a facility with automatic fire suppression. Totally noncombustible storage (no cardboard, wood, etc.) is satisfactory.

2. The door between $190 \mathrm{KW}$ and $165 \mathrm{KW}$ should be kept closed. Signs and/or administrative controls should be implemented to insure the doors stay closed.

3. If the number of occupants increase to ten or more, than emergency lighting, manual pull stations, occupant notification, and exit signs should be installed.

4. No storage shall be allowed in the basement. Do not install fire sprinklers in the basement.

5. Apply for an exemption to DOE Order 5480.7A requirement for the installation of automatic fire suppression sprinklers, including the basement, if the MPFL exceeds $\$ 1$ million.

\subsubsection{Building 1706KE/KEL}

1. Do not install automatic fire sprinklers. The facility normally has less than ten occupants, housekeeping was in good order, and the facility in noncombustible construction.

2. Apply for an exemption to DOE Order 5480.7A requirement for the installation of automatic fire suppression sprinklers if the MPFL exceeds $\$ 1$ million.

\subsubsection{Building 1706KER}

1. Do not install automatic fire sprinklers. 
2. Apply for an exemption to DOE Order $5480.7 \mathrm{~A}$ requirements for the installation of automatic fire suppression sprinklers if the MPFL exceeds $\$ 1$ million.

\subsubsection{Building 1717K}

1. Correct the problem causing the need to install heat tracing on the fire sprinkler piping on the west room of the building. Remove the heat tracing from the fire sprinkler piping.

\subsection{JACK POOLE'S EVALUATION/RECOMMENDATIONS}

These recommendations are based upon the information as discussed in Section 5.0 and the walk-through. The recommendations as identified below are provided based upon considering several key components for making an engineering evaluation/justification. Key components that were evaluated in making every recommendation is as follows:

- Occupancy of the facility,

- Number of building occupants,

- Available ignition sources,

- Combustible loading throughout the facility (fixed and transient),

- Adequacy and condition of existing fire suppression system(s),

- Adequacy and condition of existing fire alarm and detection system(s),

- Value of the facility and the contents,

- Potential of radiation contamination to the public and the environment from a fire, and

- Future use and limited remaining service life of the facility.

Recommended exemptions are proposed to Westinghouse Hanford to be submitted to DOE. These recommendations have considered the life safety of the building occupants, potential release of radiological contaminates to the public and the environment, the limited remaining service life, and the value of the facility. Exemption requests will have to be justified by additional evaluation.

\subsubsection{Building 105KE}

The primary function of Building $105 \mathrm{KE}$ is the storage of irradiated $\mathrm{N}$ Reactor fuel in the basin and the monitoring of the fuel. Recommendations identified in Fire Barrier Evaluation of the Wall Between Spent Nuclear Fuel Storage Basins and Reactor Areas, of $105 \mathrm{KE}$ and $105 \mathrm{KW}$ (WHC 1994b), should be implemented to upgrade the barrier to separate the facility into two fire areas. The active side would be required to be provided with automatic sprinklers throughout according to DOE Order 5480.7A if the MPFL exceeds $\$ 1$ million. Office/support areas of the facility are sprinklered except for a few rooms. The basin area and the basement below the office/support areas are not sprinklered. The only combustibles in these areas are the insulation on cables in the basement and about six bags of contaminated protective clothing in the west loading area of the basin. 

follows:

The recommendations for $105 \mathrm{KE}$, based on a 6 -year remaining service life, are as

1. Upgrade the barrier that separates the active areas from the D\&D areas with respect to Fire Barrier Evaluation of the Wall Between Spent Nuclear Fuel Storage Basins and Reactor Areas, 105KE and 105KW (WHC 1994b).

2. Provide additional sprinklers in the office/support areas to provide complete coverage.

3. Do not add sprinklers in the basin area, in the basement below the office/support areas or in the D\&D areas. This will not be cost effective since the construction is noncombustible, combustible loading is limited and the ignition sources are adequately controlled.

4. Complete the work packages to upgrade the emergency lighting in the active areas with respect to NFPA 101.

5. Remove all transient combustibles from the $D \& D$ area. Since a recommendation is not made to provide sprinklers in this area, all combustible loading should be removed to reduce the fire endurance. follows:

The recommendations for $105 \mathrm{KE}$ based on a 12-year remaining service life, are as

1. Complete all recommendations as described above for a limited remaining service life of 6 years.

2. Upgrade the fire alarm system in the active areas to provide manual pull stations and occupant notification in accordance with NFPA 72. A wireless system should be considered to reduce the installation costs. All circuits shall be supervised as specified in the National Fire Alarm Code.

Request exemptions for installing automatic fire suppression sprinklers in the following areas:

- Apply for an exemption to DOE Order 5480.7A for the deletion of sprinklers in the D\&D areas.

- Apply for an exemption to DOE Order 5480.7A for the deletion of sprinklers in the storage basin.

- Apply for an exemption to DOE Order 5480.7A for the deletion of sprinklers in the basement area below the office areas.

\subsubsection{Building $105 \mathrm{KW}$}

The primary function of Building $105 \mathrm{KW}$ is the storage of irradiated $\mathrm{N}$ Reactor fuel in the basin and the monitoring of the fuel. Recommendations identified in Fire Barrier Evaluation of the Wall Between Spent Nuclear Fuel Storage Basins and Reactor 
Areas, 105KE and 105KW (WHC 1994b), should be implemented to upgrade the barrier to separate the facility into two fire areas. The active side would be required to be provided with automatic sprinklers throughout in compliance with DOE Order 5480.7A if the MPFL exceeds $\$ 1$ million. Office/support areas of the facility are sprinkled except for a few rooms. The basin area and the basement below the office/support areas are not sprinklered. The only combustibles in these areas are the insulation on cables in the basement and about six bags of contaminated protective clothing in the west loading area of the basin. follows:

The recommendations for $105 \mathrm{KE}$, based on a 6-year remaining service life are as

1. Upgrade the barrier that separates the active areas from the D\&D areas according to Fire Barrier Evaluation of the Wall Between Spent Nuclear Fuel Storage Basins and Reactor Areas, 105KE and 105KW (WHC 1994b).

2. Provide additional sprinklers in the office/support areas to provide complete coverage.

3. Do not add sprinklers in the basin area, in the basement below the office/support areas, in the space between the two roofs over the basin, or in the D\&D areas. This would not be cost effective since the construction is noncombustible, combustible loading is limited, and the ignition sources are adequately controlled.

4. Complete the work packages to upgrade the emergency lighting in the active areas with respect to NFPA 101.

5. Remove all transient combustibles from the D\&D area. Since a recommendation is not made to provide sprinklers in this area, all combustible loading should be removed to reduce the fire endurance. follows:

The recommendations for $105 \mathrm{KE}$, based on a 12 -year remaining service life, are as

1. Complete all recommendations as described above for a limited remaining service life of 6 years.

2. Upgrade the fire alarm system in the active areas to provide manual pull stations and occupant notification in accordance with NFPA 72. The use of a wireless system should be investigated to reduce the installation costs. All circuits shall be supervised with respect to the National Fire Alarm Code.

Request exemptions for installing automatic fire suppression sprinklers in the following areas:

- Apply for an exemption to DOE Order 5480.7A for the deletion of sprinklers in the D\&D areas. 
- Apply for an exemption to DOE Order 5480.7A for the deletion of sprinklers below the new metal roof over the storage basin.

- Apply for an exemption to DOE Order 5480.7A for the deletion of sprinklers in the storage basin.

- Apply for an exemption to DOE Order 5480.7A for the deletion of sprinklers in the basement area below the office areas.

\subsubsection{Switching Station 151K}

The separation distance of $140 \mathrm{ft}$ between $1717 \mathrm{~K}$ and the oil-filled breakers is adequate. Access into the switching station yard is controlled by a locked security fence that is provided with two gates. The yard is maintained free of combustibles and vegetation. There are no recommendations for this switching station for a remaining service life of 6 or 12 years.

\subsubsection{Substation 151KE}

The separation distance of $15 \mathrm{ft}$ between $165 \mathrm{KE}$ and the oil-filled transformers is not the recommended separation distance according to FM Loss Prevention Data Sheet 5 -4. The east exterior wall of $165 \mathrm{KE}$ is substantial reinforced concrete, but there are several vent penetrations that are not protected with an approved fire damper or fire shutter. The east wall is constructed so there is an overhang and the existing shutters are not directly exposed to the transformers. Due to the substantial construction of the existing shutters, it is expected that they will provide adequate fire resistance if maintained in the closed position. Since the recommended separation distance as specified in FM Loss Prevention Data Sheet 5-4 is $25 \mathrm{ft}$ from noncombustible construction and the actual separation distance is $15 \mathrm{ft}$, and the fact that the existing shutters are not directly exposed, it is not recommended that the existing shutters be replaced with approved fire shutters or the transformers be provided with a waterspray suppression system.

Access into the switching station yard is controlled by a locked security fence that is provided with two gates. The yard is maintained free of combustibles and vegetation. There are no recommendations for this substation for a remaining service life of 6 or 12 . years.

\subsubsection{Substation 151KW}

The separation distance of $15 \mathrm{ft}$ between $165 \mathrm{KW}$ and the oil-filled transformers is not the recommended separation distance according to FM Loss Prevention Data Sheet 5-4. The east exterior wall of $165 \mathrm{KW}$ is substantial reinforced concrete, but there are several vent penetrations that are not protected with an approved fire damper or fire shutter. The east wall is constructed so there is an overhang and the existing shutters are not directly exposed to the transformers. Due to the substantial construction of the existing shutters, it is expected that they will provide adequate fire resistance if maintained in the closed position. Since the recommended separation distance as specified in FM Loss Prevention Data Sheet 5-4 is $25 \mathrm{ft}$ from noncombustible construction and the actual separation distance is $15 \mathrm{ft}$, and the fact that the existing shutters are not 
directly exposed, it is not recommended that the existing shutters be replaced with approved fire shutters or the transformers be provided with a waterspray suppression system.

Access into the switching station yard is controlled by a locked security fence that is provided with two gates. The yard is maintained free of combustibles and vegetation. There are no recommendations for this substation for a remaining service life of 6 or 12 years.

\subsubsection{Building 165KE}

Current occupancy of $165 \mathrm{KE}$ is industrial. The combustible loading in the facility is low. There is some switchgear in the east portion of the building that is active; however, this switchgear is not vital for the cooling water for the storage in the $105 \mathrm{KE}$ basin. Although the replacement cost of the facility is greater than $\$ 1$ million, it is not expected that the MPFL will exceed $\$ 1$ million or that the loss of the equipment will create an unacceptable delay. If the FHA for the building indicates that the MPFL exceeds $\$ 1$ million, an automatic suppression system should be provided to comply with DOE Order 5480.7A. However, it is not recommended that an automatic suppression system be provided since the building is normally unoccupied, the combustible loading is low, and the heat detection system in the switchgear room is operational, will transmit an alarm to the fire department, and is tested and maintained. follows:

The recommendations for $165 \mathrm{KE}$, based on a 6 -year remaining service life, are as

1. The doors in the barrier between $165 \mathrm{KE}$ and $190 \mathrm{KE}$ should remain in the closed position to provide separation between the two buildings. Signs and/or administrative controls should be implemented to ensure the doors stay closed. This wall is not a rated fire barrier, but due to the limited combustible loading and the substantial construction of the barrier, it is expected the barrier will provide a minimum of $2 \mathrm{-hr}$ fire resistance rating.

2. The existing shutters in the east exterior wall should remain in the closed position to limit the exposure of the transformers. Signs and/or administrative controls should be implemented to ensure the shutters stay closed.

3. Since the facility is not normally occupied and the Life Safety Code does not require emergency lighting, it is not recommended that the work package to upgrade the emergency lighting in the facility be completed. follows:

The recommendations for $165 \mathrm{KE}$, based on a 12-year remaining service life, are as

1. Complete all recommendations as described above for a limited remaining service life of 6 years.

2. Complete the work package to upgrade the fire detection system (heat detectors in the switchgear room) to provide supervised initiating circuits and to replace the romex with approved wiring as specified in NFPA 72. Although a fire 
alarm system is not required for this unoccupied facility, it is recommended that the existing system be upgraded according to the work package to limit the loss.

Request exemption for installing automatic fire suppression sprinklers in the following areas:

- Apply for an exemption to DOE Order 5480.7A for the deletion of sprinklers in all areas including the basement.

\subsubsection{Building $165 \mathrm{KW}$}

Current occupancy of $165 \mathrm{KW}$ is industrial. The combustible loading in the facility is low. There is some switchgear in the east portion of the building that is active; however, this switchgear is not vital for the cooling water for the storage in the 105KW basin. Although the replacement cost of the facility is greater than $\$ 1$ million, it is not expected that the MPFL will exceed $\$ 1$ million or that the loss of the equipment will create an unacceptable delay. If the FHA for the building indicates that the MPFL exceeds $\$ 1$ million, an automatic suppression system should be provided to comply with DOE Order 5480.7A. However, it is not recommended that an automatic suppression system be provided since the building is normally unoccupied, the combustible loading is low, and the heat detection system in the switchgear room is operational, will transmit an alarm to the fire department, and is tested and maintained. follows:

The recommendations for $165 \mathrm{KW}$, based on a 6-year remaining service life, are as

1. The doors in the barrier between $165 \mathrm{KW}$ and $190 \mathrm{KW}$ should remain in the closed position to provide separation between the two building. Signs and/or administrative controls should be implemented to ensure the doors stay closed. This wall is not a rated fire barrier, but due to the limited combustible loading and the substantial construction of the barrier, it is expected the barrier will provide a minimum of 2 -hr fire resistance rating.

2. The existing shutters in the east exterior wall should remain in the closed position to limit the exposure of the transformers. Signs and/or administrative controls should be implemented to ensure the shutters stay closed. as follows:

The recommendations for $165 \mathrm{KW}$, based on a 12-year remaining service life, are

1. Complete all recommendations as described above for a limited remaining service life of 6 years.

2. Upgrade the fire detection system (heat detectors in the switchgear room) to provide supervised initiating circuits and to replace the romex with approved wiring according to NFPA 72. Although a fire alarm system is not required for this unoccupied facility, it is recommended that the existing system be upgraded with respect to the work package to limit the loss. 
WHC-SD-W405-PD-002, Rev. 0

Request exemption for installing automatic fire suppression sprinklers in the following areas:

- Apply for an exemption to DOE Order 5480.7A for the deletion of sprinklers in all areas including the basement.

\subsubsection{Building/Tunnel 167K}

There are no recommendations for this unoccupied tunnel that has a very low combustible loading.

\subsubsection{Building 183KE}

Building $183 \mathrm{KE}$ is a low hazard industrial occupancy with an occupant load of less than ten. The building is not provided with an automatic suppression or automatic alarm and detection system. The FHA was not completed at the time this report was developed; therefore, it is unknown if the MPFL exceeds $\$ 1$ million. If the MPFL exceeds $\$ 1$ million, it is not recommended that an automatic suppression system be provided, due to the low combustible loading, there are no special hazards, and the occupant load is low.

There is a separation distance of $18 \mathrm{ft}$ between $183 \mathrm{KE}$ and the oil-filled transformers. This distance is not the recommended separation distance in compliance with FM Loss Prevention Data Sheet 5-4. The east exterior wall of $183 \mathrm{KW}$ is noncombustible construction. Recommended separation distance in compliance with FM Loss Prevention Data Sheet 5-4 is $25 \mathrm{ft}$ from noncombustible construction and the actual separation distance is $18 \mathrm{ft}$. However, it is not recommended that the wall be upgraded to a fire rated barrier, the transformers be relocated, or the transformers be provided with a waterspray suppression system. These improvements are not costeffective given the existing separation distance and limited remaining service life of the facility. follows:

The recommendation for $183 \mathrm{KE}$, based on a 6 -year remaining service life, are as

1. The building should be provided with manual pull stations and occupant = notification if the occupant load increases. If the occupant load remains less than ten the fire alarm system is not recommended.

2. Complete the work packages to upgrade the emergency lighting and the exit signs. follows:

The recommendations for $183 \mathrm{KE}$, based on a 12 -year remaining service life, is as

1. Complete the recommendation as described above for a limited remaining service life of 6 years.

Request exemption for installing automatic fire suppression sprinklers in the following areas: 
- Apply for an exemption to DOE Order 5480.7A for the deletion of sprinklers in all areas of the building.

\subsubsection{Building 190KE}

The proposed plan for this facility is to build a two-story office building within this building and use the remaining areas for storage and a maintenance shop. Based upon the future proposed use, the following recommendations should be implemented independent of the limited remaining service life.

1. All areas (except the basement) shall be provided with automatic sprinklers, inclusive of the new office areas, storage areas, and maintenance shop. Sprinkler protection below the existing roof is adequate for the storage and maintenance shop areas if a suspended ceiling is not being provided for these areas. The sprinklers in the new office areas shall comply with NFPA 13. The sprinklers in the storage areas shall be designed following NFPA 231 or 231C depending on the storage commodity and arrangement.

2. All areas shall be provided with manual pull stations and occupant notification according to the Life Safety Code and NFPA 72.

3. Emergency lighting shall be provided for all areas.

4. Exit signs shall be provided as required in accordance with the Life Safety Code.

If the proposed modifications to the facility are not implemented the following recommendations shall be implemented, based on a 6-year remaining service life:

1. Install automatic sprinklers throughout the main floor of the building but not the basement if the storage media remains as is, since this equipment and materials is needed for operation and D\&D activities of the K Area facilities.

2. The use, storage, and handling of the flammable and combustible liquids in the northeast corner of the building should be modified to comply with NFPA 30 .

3. The location of the existing flammable liquid cabinets should be modified to comply with NFPA 30 or the number of flammable liquid cabinets reduced to three within a $100-\mathrm{ft}$ radius.

4. Doors in the barrier between $190 \mathrm{KE}$ and $165 \mathrm{KE}$ should remain in the closed position. Signs and/or administrative procedures should be implemented to ensure the doors remain closed.

5. All combustibles located in the basement should be removed. 
WHC-SD-W405-PD-002, Rev. 0

If the proposed modifications to the facility are not implemented and the facility is to be used as is, the following recommendations should be implemented based on a 12-year remaining service life:

1. Complete the recommendation as described above for a limited remaining service life of 6 years.

2. Provide emergency lighting throughout the facility in accordance with NFPA 101.

3. If the occupant load increases, manual pull stations and occupant notification should be provided for the facility.

Request exemption for installing automatic fire suppression sprinklers in the following areas:

- $\quad$ Apply for an exemption to DOE Order 5480.7A for the deletion of sprinklers in all areas including the basement, unless the proposed modifications are implemented as planned. If the proposed modifications are implemented, the entire building (all areas) should be provided with sprinklers, manual pull stations and occupant notification as required by NFPA Codes and Standards.

\subsubsection{Building 190KW}

The following recommendations should be implemented based on a 6-year remaining service life:

1. The doors in the barrier between $190 \mathrm{KE}$ and $165 \mathrm{KE}$ should remain in the closed position. Signs and/or administrative procedures should be implemented to ensure the doors remain closed.

2. If the building is being used for the storage of materials or equipment needed for operation of active areas or D\&D activities in the deactivated areas, and has a value of $\$ 1$ million with respect to the FHA, an automatic suppression system should be provided.

The following recommendations should be implemented based on a 12-year remaining service life:

1. Complete the recommendation as described above for a limited remaining service life of 6 years.

2. If the occupant load increases, manual pull stations and occupant notification should be provided for the facility.

Request exemption for installing automatic fire suppression sprinklers in the following areas: 

sprinklers in all areas.

\subsubsection{Building 1706KE/KTL}

There is a separation distance of 18 - $\mathrm{ft}$ between $1706 \mathrm{KE}$ and the de-activated, oilfilled transformers. This distance is not the recommended separation distance of $25-\mathrm{ft}$ with respect to FM Loss Prevention Data Sheet 5-4. The north exterior wall of 1706KE is noncombustible construction. Although the recommended minimum separation distance according to FM Loss Prevention Data Sheet 5-4 is not being met, it is not recommended that the wall be upgraded to a fire rated barrier, the transformers be relocated or the transformers be provided with a waterspray suppression system. There is no ignition source resident in the transformers, so they represent very little fire risk.

There are no recommendations for this facility provided a 6 or 12 year remaining service life.

Request exemption for installing automatic fire suppression sprinklers in the following areas:

- $\quad$ Apply for an exemption to DOE Order 5480.7A for the deletion of sprinklers in all areas.

\subsubsection{Building 1706KER}

There is a separation distance of $12 \mathrm{ft}$ between 1706KER and the oil-filled transformers. This distance is not the recommended separation distance according to FM Loss Prevention Data Sheet 5-4. The south exterior wall of 1706KER is noncombustible construction. Although the recommended separation distance with respect to FM Loss Prevention Data Sheet 5-4 is $25 \mathrm{ft}$ from noncombustible construction and the actual separation distance is $12 \mathrm{ft}$, it is not recommended that the wall be upgraded to a fire rated barrier, the transformers be relocated, or the transformers be provided with a waterspray suppression system. There is no ignition source resident in the de-activated transformers, so they represent very little fire risk. as follows:

The recommendation for $1706 \mathrm{KER}$, based on a 6-year remaining service life, is

1. Remove the combustibles that are stored in the two office areas located on the first floor to limit the loss and reduce the risk of radiological contamination as a result of a fire. as follows:

The recommendation for $1706 \mathrm{KER}$, based on a 12 -year remaining service life, is

1. Complete the recommendation as described above for a limited remaining service life of 6 years. 


\subsubsection{Building 1717K}

Building $1717 \mathrm{~K}$ is a $10,800 \mathrm{ft}^{2}$ noncombustible facility, having a mixed occupancy for business and industrial. The building is provided with a complete automatic sprinkler system and manual pull stations are provided at the three exits. The housekeeping in the facility was good. follows:

The recommendation for $1717 \mathrm{~K}$, based on a 6 -year remaining service life, is as

1. Provide sufficient heat to the west garage area and remove the heat tracing on the sprinkler piping. follows:

The recommendation for $1717 \mathrm{~K}$, based on a 12 -year remaining service life, is as

1. Complete the recommendation as described above for a limited remaining service life of 6 years. 
WHC-SD-W405-PD-002, Rev. 0

\subsection{REFERENCES}

\subsection{FACHITY DOCUMENTATION}

WHC, 1994a, Engineering Study for 100K Area Fire Protection Upgrades, WHC-SDN037-ES-001, Rev. 0, March 1994, Westinghouse Hanford Company, Richland, Washington.

WHC, 1994b, Fire Barrier Evaluation of the Wall Between Spent Nuclear Fuel Storage Basins and Reactor Areas, 105KE and 105KW, WHC-SD-W405-PD-001, Rev. 0, September 1994, Westinghouse Hanford Company, Richland, Washington.

WHC, 1994c, Internal Memorandum To; Project N037 Files, From: Project Engineering and Integration, July 20, 1994, Subject: Project N037; Disposition of FY 92 Fire Protection Findings, 94-BHJ-018, Westinghouse Hanford Company, Richland, Washington.

WHC, 1994d, cc: Mail Memorandum To: S.C. Wallace and C.F. Myott, From: B.H. Johnson 7-25-94, Subject: Fire Protection Consultant Visit, Westinghouse Hanford Company, Richland, Washington.

WHC, 1993a, Fire Protection Program Manual, WHC-CM-4-41, April 1993,

Westinghouse Hanford Company, Richland, Washington.

WHC, 1993b, Safety Equipment List for K Area, WHC-SD-NR-SEL-001, Rev. 0, July 1993, Westinghouse Hanford Company, Richland, Washington.

WHC, 1992a, Conceptual Design Report, 100-K Area Water Supply and Distribution, WHC-SD-N027-CDR-001, Rev. 0, June 1992, Westinghouse Hanford Company, Richland, Washington.

WHC, 1992b, Project N037, 100K Area Fire Protection Upgrades Engineering Study, 1992, Westinghouse Hanford Company, Richland, Washington.

WHC, 1984, Safety Analysis Report, Handling and Storage of Irradiated N Reactor Fuel in 105KE and KW Fuel Storage Facilities, UNI-M-143, Rev. 1, January 1984, . UNC Nuclear Industries, Richland, Washington.

WHC, 1987, A Preliminary Assessment of $N$ Reactor Graphite Combustion Risks, WHCIP-0022, Rev. 0, October 1987, Westinghouse Hanford Company, Richland, Washington. 


\section{DRAWINGS}

H-1-21000 Drawing Index Architectural and Structural

H-1-21001 Architectural Key Plan at Elev. 0-ft, 0-in.

H-1-21002 Architectural Floor Plans Below 0-ft, 0-in. and Below -17-ft, 6-in., Process Area

H-1-21004 Architectural Floor Plan at Elev. 0-ft, 0-in. Process Area

H-1-21005 Architectural Floor Plan at Elev. 15-ft, 0-in. Process Area

H-1-21006 Architectural Floor Plan at Elev. 28-ft, 0-in. Process Area

H-1-21007 Architectural Floor Plan at Elev. 0-ft, 0-in. Storage and Transfer Area

H-1-21008 Architectural Floor Plan at Elev. 15-ft, 0-in. Storage and Transfer Area

H-1-21009 Architectural Floor Plan at Elev. 28-ft, 0-in. Storage and Transfer Area

H-1-21010 Architectural Floor Plan at Elev. 38-ft, 0-in. Storage and Transfer Area

H-1-21011 Architectural Floor Plan at Elev. 51-ft, 7-in. Process Area

H-1-21012 Architectural Floor Plans at Elev. 66-ft, 0-in. and 90-ft, 2-in.

\subsection{DOE ORDERS AND CRITERIA}

DOE Order 6430.1A, General Design Criteria, 1989.

DOE Order 5480.7A, Fire Protection, 1993.

RLID 5480.7, Fire Protection, 1994. 
7.4 NATIONAL FIRE PROTECTION ASSOCIATION CODES/STANDARDS

NFPA 10 - Standard on Portable Fire Extinguishers, 1990.

NFPA 13 - Standard on the Installation of Automatic Sprinkler Systems, 1994.

NFPA 20 - Standard on the Installation of Centrifugal Fire Pumps, 1993.

NFPA 22 - Standard on Water Tanks for Private Fire Protection, 1993.

NFPA 24 - Standard on the Installation of Private Fire Service Mains and Their Appurtenances, 1992.

NFPA 72 - National Fire Alarm Code, 1993.

NFPA 80 - Standard for Fire Doors and Fire Windows, 1992.

NFPA 101 - Life Safety Code, 1994.

NFPA 220 - Standard Types of Building Construction, 1992.

NFPA 252 - Standard Methods of Fire Tests of Door Assemblies, 1990.

NFPA 801 - Recommended Fire Protection Practice for Facilities Handling Radioactive Materials, 1991.

7.5 FACTORY MUTUAL LOSS PREVENTION DATA SHEETS

Loss Prevention Data Sheet 1-19, Fire Walls, Subdivisions and Draft Curtains, June 1991.

Loss Prevention Data Sheet 1-21, Fire Resistance Building Assemblies, July 1977.

Loss Prevention Data Sheet 1-23, Protection of Openings, August 1977.

Loss Prevention Data Sheet 5-4, Transformers.

7.6 OTHERDOCUMENTS

DOE Fire Protection Resource Manual.

NFPA Fire Protection Handbook, 17th Edition.

SFPE Fire Protection Engineering Handbook, First Edition.

American Nuclear Insurers Fire/All-Risk Guidelines, November 1990. 